\title{
Synthesis, Characterization and Photovoltaic Properties of Di-Anchoring Organic Dyes
}

\author{
Tzi-Yi Wu, ${ }^{a, b}$ Ming-Hsiu Tsao, ${ }^{a}$ Shyh-Gang Su, ${ }^{a}$ H. Paul Wang, ${ }^{c, d}$ Yuan-Chung Lin, ${ }^{e}$ \\ Fu-Lin Chen, ${ }^{a}$ Cheng-Wen Chang ${ }^{a}$ and I-Wen Sun ${ }^{*, a, c}$
}

${ }^{a}$ Department of Chemistry, ${ }^{c}$ Sustainable Environment Research Center and ${ }^{d}$ Department of Environmental Engineering, National Cheng Kung University, Tainan 701, Taiwan

${ }^{b}$ Department of Polymer Materials, Kun Shan University, Tainan 71003, Taiwan

${ }^{e}$ Institute of Environmental Engineering, National Sun Yat-Sen University, Kaohsiung 804, Taiwan

\begin{abstract}
Três novos pigmentos orgânicos contendo grupamentos carbazol, iminodibenzil e fenotiazina como doadores de elétrons e anéis rodanina bi-ancoradores como receptores de elétrons, foram sintetizados e avaliados como fotossensibilizadores em células solares. Células solares empregando corantes com grupos fenotiazinas como unidades transportadora de buracos e anéis rodanina biancoradores como receptores de elétrons exibiram uma densidade de fotocorrente de curto circuito de $10,6 \mathrm{~mA} \mathrm{~cm}{ }^{-2}$, voltagem de circuito aberto de $0,658 \mathrm{~V}$ e fator de preenchimento de 0,7 , correspondendo a uma eficiência de conversão total de $4,91 \%$ sob luz solar padrão AM 1.5 .
\end{abstract}

Three new organic dyes comprising carbazole, iminodibenzyl and phenothiazine moieties, as electron donors and di-anchoring rhodanine rings as the electron acceptors, were synthesized and evaluated for use in dye-sensitized solar cells. A solar cell employing dye-containing phenothiazine as a hole-transporting unit and di-anchoring rhodanine rings as the electron acceptors exhibits a short circuit photocurrent density of $10.6 \mathrm{~mA} \mathrm{~cm}{ }^{-2}$, an open-circuit voltage of $0.658 \mathrm{~V}$ and a fill factor of 0.7 , corresponding to an overall conversion efficiency of $4.91 \%$ at standard AM 1.5 sunlight.

Keywords: dye-sensitized solar cells, electrochemistry, organic dyes, electron donor, rhodanine

\section{Introduction}

Compounds with extending conjugated $\pi$-electron systems are of importance in a wide variety of applications, such as optical, electronic, optoelectronic and magnetic materials. ${ }^{1-7}$ The development of organic electroactive and photoactive materials has progressed significantly in recent years due to their potential applications in optoelectronic devices, such as electroluminescence (EL) devices, photovoltaic devices, thin film transistors and solid-state lasers. ${ }^{8,9}$ Donor-acceptor (D-A) organic molecules are one of the most important conjugated organic materials; they have attracted considerable attention as electroluminescent (EL) materials for organic light-emitting diodes (OLEDs) and as photovoltaic materials for organic solar

*e-mail: iwsun@mail.ncku.edu.tw cells. The physical and chemical properties of donoracceptor materials can be modified by selecting suitable donor moieties or/and acceptor moieties.

Studies of donor (D)- $\pi$ (bridge)-acceptor (A) chromophores have found that the intramolecular charge transfer characteristics of these molecules in the excited state are essential for dye sensitizers in dyesensitized solar cells (DSSCs), ${ }^{10}$ since the light-induced intramolecular electron transfer can easily occur from the electron donor to the electron acceptor through the $\pi$-bridge, which favors photocurrent generation. ${ }^{11} \mathrm{D}$-A $\pi$-conjugated organic dyes have several advantages, such as their ease of synthesis, high molar extinction coefficient, tunable absorption spectral response from the visible to the near infrared (NIR) region, environmental friendliness and inexpensive production techniques compared to those for Ru complexes. In addition, both modeling and experimental results have shown that 
anchoring units, such as carboxylic groups, are necessary for efficient dye adsorption on the surface of $\mathrm{TiO}_{2}$ to favor charge injection. ${ }^{12}$

Recently, impressive photovoltaic performance has been reported for some organic coumarin, ${ }^{13}$ indoline, ${ }^{14}$ merocyanine,${ }^{15}$ and hemicyanine dyes. ${ }^{16}$ Reasonable photo-conversion efficiencies have been achieved with some push-pull-type organic chromophores. ${ }^{17}$ However, due to the formation of dye aggregates on the semiconductor surface and the presence of unstable radical species during redox reaction cycles, many organic dyes exhibit conversion efficiency and operational stability lower than those of metalcomplex dyes in DSSCs. Thus, it is desired to develop efficient stable organic dyes which do not aggregate. Phenothiazine is a well-known heterocyclic compound that has electron rich sulfur and nitrogen heteroatoms. Iminodibenzyl is a diphenylamine, wherein two ortho positions are joined by a dimethylene bridge. Phenothiazine-based organic dyes have found numerous applications in electronics and optoelectronics, including light-emitting diodes, ${ }^{18}$ photovoltaic cells, thin film transistors, ${ }^{19}$ and electrochromic cells. ${ }^{20,21}$ The highly nonplanar structure of iminodibenzyl and phenothiazine units impedes $\pi$-stacking aggregation and intermolecular excimer formation, making them suitable for diverse optoelectronic applications. ${ }^{22}$

In previous work, Wu et al. ${ }^{23}$ have reported some organic dyes with a rhodanine ring as mono-anchoring acceptors. In the present work, new metal-free carbazole, iminodibenzyl and phenothiazine sensitizers with two electron acceptors of rhodanine-3-acetic acid are reported. These acceptor-donor-acceptor $\pi$-conjugated dyes with an amine derivative act as the electron donors and two rhodanine-3-acetic acid moieties acts as the anchoring group for attachment on the metal oxide and as the electron acceptors. A $\pi$-conjugated methane unit connects the donor and acceptor units. We investigate the electron-donating nature and structural variations of the amine unit and study its optical, electrochemical and photovoltaic properties.

\section{Experimental}

\section{Chemicals}

All starting materials and tetrabutylammonium perchlorate (TBAP) were commercial available and used as received. 1,2-dimethyl-3-propylimidazolium iodide (DMPImI) were synthesized and purified according to a procedure in the literature. ${ }^{24}$

\section{Preparation of dye-sensitized $\mathrm{TiO}_{2}$ electrode (photoanode)} and counter electrode

The working $\mathrm{TiO}_{2}$ electrode (photoanode) and counter electrode for dye-sensitized solar cells were prepared as follows. F-doped tin oxide (FTO) glass plates (3 mm thick, $7 \Omega \mathrm{cm}^{-2}$ ) were first cleaned in a cleaning detergent aqueous solution with an ultrasonic bath for $15 \mathrm{~min}$ and rinsed with water and ethanol. Then, the FTO electrodes were immersed into $40 \mathrm{mmol} \mathrm{L}^{-1} \mathrm{TiCl}_{4}$ (aqueous) at $70{ }^{\circ} \mathrm{C}$ for $30 \mathrm{~min}$ and rinsed with water and ethanol. Two kinds of $\mathrm{TiO}_{2}$ paste, containing nanocrystalline $\left(c a .25 \mathrm{~nm}\right.$ ) $\mathrm{TiO}_{2}$ (Degussa P25, paste $\mathrm{A}$ ) and $500 \mathrm{~nm}$ submicroparticle $\mathrm{TiO}_{2}$ (TOHO, Japan, paste B), respectively, were prepared using a previously reported procedure. ${ }^{25}$ To prepare paste $\mathrm{A}$, commercial titania powder (3 g, Degussa P25) was ground in a mortar with a small amount of water $(1 \mathrm{~mL})$ containing acetylacetone $(0.1 \mathrm{~mL})$, which was added to prevent reaggregation of the particles. After the $\mathrm{TiO}_{2}$ particles were dispersed, the paste was diluted by the slow addition of water $(3 \mathrm{~mL})$ under continued grinding and a surfactant, Triton X-100 $(0.05 \mathrm{~mL})$, was added to facilitate the spreading of the colloid on the substrate. Paste A was kept in ultrasound bath for about $24 \mathrm{~h}$, at $28^{\circ} \mathrm{C}$. Paste B was prepared by a similar method. The spin coating procedure for paste A was repeated to get the appropriate thickness of $\mathrm{TiO}_{2}$ films $(12 \mu \mathrm{m})$. After paste A was dried at $125^{\circ} \mathrm{C}$, paste $\mathrm{B}$ was coated two more times, in such a way that the $\mathrm{TiO}_{2}$ films with $500 \mathrm{~nm}$ particles for the scattering layer were $c a .4 \mu \mathrm{m}$ thick. The electrodes coated with $\mathrm{TiO}_{2}$ pastes were gradually heated $\left(5^{\circ} \mathrm{C} \mathrm{min}^{-1}\right)$ under airflow up to $450^{\circ} \mathrm{C}$, which was kept for $30 \mathrm{~min}$. The electrodes were treated with $40 \mathrm{mmol} \mathrm{L}^{-1}$ solution of $\mathrm{TiCl}_{4}$ in (solvent ethanol). $\mathrm{The}^{\mathrm{TiO}}{ }_{2}$ films were then rinsed with water and ethanol and sintered again at $450{ }^{\circ} \mathrm{C}$ for $30 \mathrm{~min}$. An active area of $0.5 \times 0.5 \mathrm{~cm}$ was selected from a sintered electrode. The electrodes were immersed in a $5 \times 10^{-4} \mathrm{~mol} \mathrm{~L}^{-1}$ solution of dye containing tetrahydrofuran (THF). Dye coatings were applied at room temperature for 24-30 h. The dye-adsorbed $\mathrm{TiO}_{2}$ films were taken out and rinsed with dry ethanol. The rinsing process was repeated several times to remove unbound dyes completely. Finally, the dye-adsorbed $\mathrm{TiO}_{2}$ films were dried in air. Counter electrodes were prepared by sputtering a $50 \mathrm{~nm}$ thick platinum layer on an FTO substrates using a Hitachi E 1045 instrument and controlling the amount of sputtered platinum with a quartz crystal thickness monitor. The thicknesses of the $\mathrm{TiO}_{2}$ films were determined by profilometry.

\section{DSSC assembly}

The dye adsorbed $\mathrm{TiO}_{2}$ electrode and Pt-counter electrode were assembled into a sandwich sealed type cell by heating 
them with hot-melt ionomer film ( $25 \mu \mathrm{m}$ thick, Solaronix) as a spacer. A drop of electrolyte solution $\left[0.1 \mathrm{~mol} \mathrm{~L}^{-1} \mathrm{LiI}\right.$, $0.05 \mathrm{~mol} \mathrm{~L}^{-1} \mathrm{I}_{2}, 0.6 \mathrm{~mol} \mathrm{~L}^{-1}$ DMPII, $0.5 \mathrm{~mol} \mathrm{~L}^{-1}$ tert-butyl pyridine (TBP) in acetonitile ( $\mathrm{ACN})$ ] was injected through a hole in the counter electrode, which was then sealed with hotmelt ionomer film and glass. The electrolyte was introduced into the cell and sealed with $\mathrm{AB}$ epoxy 906 Adhesive for $30 \mathrm{~min}$. The working area of the electrode was $0.25 \mathrm{~cm}^{2}$.

\section{Characterization of the dyes and photovoltaic measurements} of the solar cells

The ${ }^{1} \mathrm{H}$ spectra were obtained on a Bruker $400 \mathrm{MHz}$ FT-NMR. Chemical shifts were reported in ppm relative to tetramethylsilane $\delta$ units. The absorption spectra of the dyes in solution and adsorbed on $\mathrm{TiO}_{2}$ films were recorded on a Cary 100 UV-Vis spectrophotometer. Fluorescence measurements were carried out using a Hitachi F-4500 fluorescence spectrophotometer. Cyclic voltammetry was performed using an electrochemical workstation $(\mathrm{CH}$ instruments Inc., CHI, model 750A) and conducted using $0.1 \mathrm{~mol} \mathrm{~L}^{-1}$ tetrabutylammonium perchlorate (TBAP) as the supporting electrolyte. The working electrode was a glassy carbon electrode, the auxiliary electrode was a Pt wire and the reference electrode was $\mathrm{Ag} / \mathrm{Ag}^{+}$. The scan rate was $100 \mathrm{mV} \mathrm{s}^{-1}$ and the temperature was $25^{\circ} \mathrm{C}$. Ferrocene was added to each sample solution at the end of the experiments. The ferrocenium/ferrocene $\left(\mathrm{Fc} / \mathrm{Fc}^{+}\right)$redox couple was used as an internal potential reference. The potential $v s$. SCE in DMF was calibrated according to a procedure published by Matsui et al. ${ }^{26}$ The photovoltaic measurements of the DSSCs were performed using a Newport M-66907 $450 \mathrm{~W}$ xenon light source through an infrared blocking filter and a Keithley 2400 digital source meter linked to a computerized control and data acquisition system. The light intensity was $1000 \mathrm{~W} \mathrm{~m}^{-2}$ under an AM 1.5 light source. Cell temperatures were kept at $25{ }^{\circ} \mathrm{C}$ during the illumination. Light intensity was calibrated using a mono-Si reference solar cell (PVM134). The incident photon-to-current conversion efficiency (IPCE) as a function of excitation wavelength was measured using an incident light $300 \mathrm{~W}$ xenon lamp. A $300 \mathrm{~W}$ xenon arc lamp solar simulator (\#91160A, Oriel) with an AM 1.5 Globe filter (\#59044, Oriel) was used to measure the I-V characteristics of the quasi-solid-state DSSC. The illumination was fixed at $100 \mathrm{~mW} \mathrm{~cm}^{-2}$ using a reference solar cell and meter (\#91150, Oriel).

\section{Computation methods}

The geometric and electronic properties of the carbazole, iminodibenzyl and phenothiazine-containing dyes S1-S3 were obtained using the Gaussian 03 program package. ${ }^{27}$ The calculation was optimized using B3LYP (Becke three parameter hybrid function with Lee-YangPerdew correlation functions) with the Pople $6-31+g(d)$ atomic basis set.

\section{Results and Discussion}

\section{Synthesis and structure of sensitizers}

In Figure 1, S1-S3 are the carbazole, iminodibenzyl and phenothiazine-containing dyes, respectively. The rhodanine dialdehydes $4 \mathbf{a}-\mathbf{c}$ were prepared using the wellknown Vilsmeier reaction in a way similar to that reported by Chen $\mathrm{et} \mathrm{al.} .^{28}$
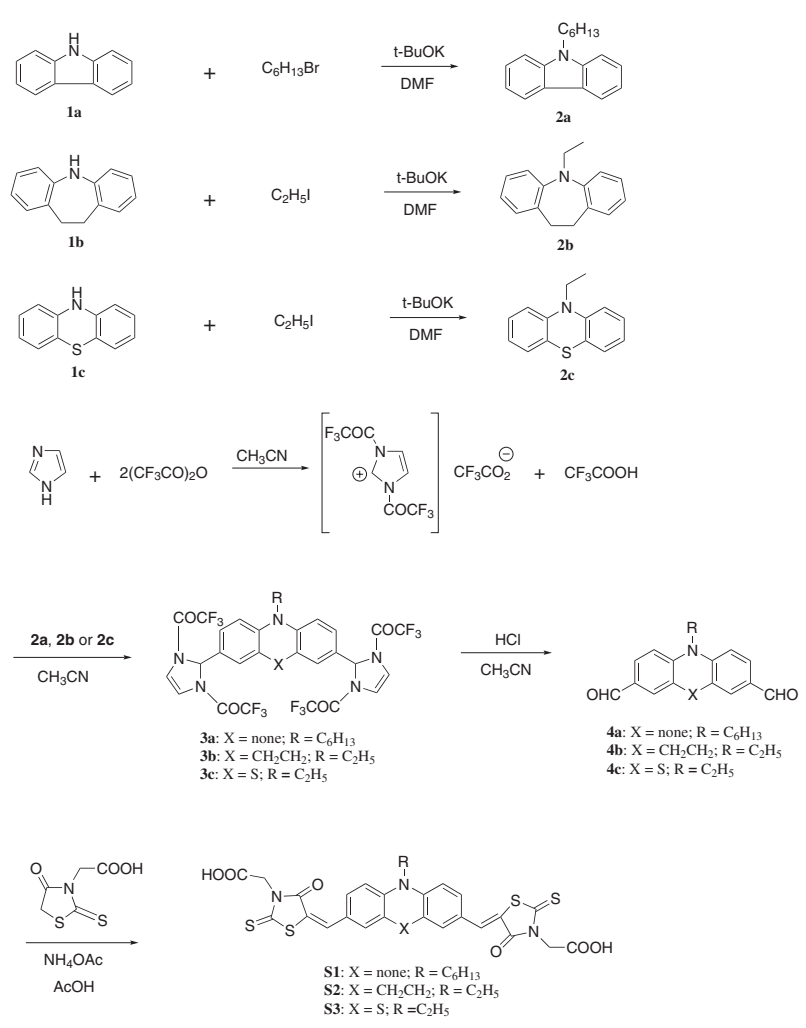

Figure 1. Synthesis of three organic dyes with double electron acceptors.

However, the Vilsmeier reaction gave low yields for the dialdehyde compounds. Therefore, a two-step strategy was used for their preparation. ${ }^{29} \mathrm{~N}$-hexylcarbazole (2a), $N$-ethyliminodibenzyl (2b) and $N$-ethylphenothiazine (2c) were first treated with a reactive derived from the reaction of imidazole and trifluoroacetic anhydride to give the respective intermediates containing trifluoroacetyl $\left(\mathrm{CF}_{3} \mathrm{CO}\right)$ groups $(\mathbf{3 a}-\mathbf{c})$ that could be readily hydrolyzed to dialdehydes (4a-c). The final products $\mathbf{S 1}, \mathbf{S 2}$ and $\mathbf{S 3}$ were obtained by the condensation of the respective aldehyde 
with rhodanine-3-acetic acid via the Knoevenagel reaction in the presence of ammonium acetate. The structural differences of those photosensitizers (Table 1 and Figure 2) were evaluated from their optimized structures. When viewed from the top, the angles $(\angle 1)$ of the $\mathbf{S} \mathbf{1}$ carbazole, the $\mathbf{S} 2$ iminodibenzyl and the $\mathbf{S 3}$ phenothiazine rings are $108.6^{\circ}, 124.4^{\circ}$ and $122.0^{\circ}$, respectively, implying that the addition of a dimethylene bridge and sulfur units significantly increases the angle $(\angle 1)$ of nitrogen atoms. The angle between two phenyl units in the carbazole unit $(\angle 4)$ is $106.4^{\circ}$; however, the angle between the phenyl unit and dimethylene bridge inside the iminodibenzyl unit $(\angle 4)$ is $125.9^{\circ}$. This can be attributed to the incorporation of a dimethylene bridge between two phenyl units increasing the steric hindrance, which increases the angles $\angle 1$ and $\angle 4$. The angle of the $\mathbf{S 3}$ phenothiazine sulfur atom $(\angle 8)$ is $99.0^{\circ}$, which is smaller than that of the phenothiazine nitrogen atom $\left(\angle 1: 122.0^{\circ}\right)$. This may be attributed to the character between nitrogen and sulfur atoms.

Table 1. Optimized geometric parameters (angle, degree) of S1, S2 and $\mathbf{S 3}$

\begin{tabular}{lccc}
\hline & S1 & S2 & S3 \\
\hline$\angle 1$ & 108.6 & 124.4 & 122.0 \\
$\angle 2$ & 125.6 & 119.1 & 118.5 \\
$\angle 3$ & 125.7 & 116.5 & 118.5 \\
$\angle 4$ & 106.4 & 125.9 & 120.5 \\
$\angle 5$ & 134.0 & 115.9 & 118.3 \\
$\angle 6$ & 106.4 & 119.6 & 120.5 \\
$\angle 7$ & 134.0 & 121.3 & 118.3 \\
$\angle 8$ & 124.3 & 115.6 & 99.0 \\
$\angle 9$ & 124.3 & 110.0 & 125.4 \\
$\angle 10$ & & 125.6 & 125.4 \\
$\angle 11$ & & 125.0 & \\
\hline
\end{tabular}

When viewed from the front, the carbazole unit is coplanar with two rhodanine rings; the dimethylene bridge decreases the coplanarity of the iminodibenzyl unit and induces the nonplanar geometry of $\mathbf{S} \mathbf{2}$. The phenothiazine is bent along the $\mathrm{N}-\mathrm{S}$ axis, as confirmed by X-ray structural analysis. ${ }^{30}$ The nitrogen atom in the phenothiazine moiety induces a nonplanar geometry similar to that of the $\mathrm{sp}^{3}$-hybridized pyramidal nitrogen.

\section{Optical properties}

The UV-Vis absorption and emission spectra of S1, S2 and S3 in DMF solution and the absorption spectra of the corresponding dyes adsorbed on $\mathrm{TiO}_{2}$ film are

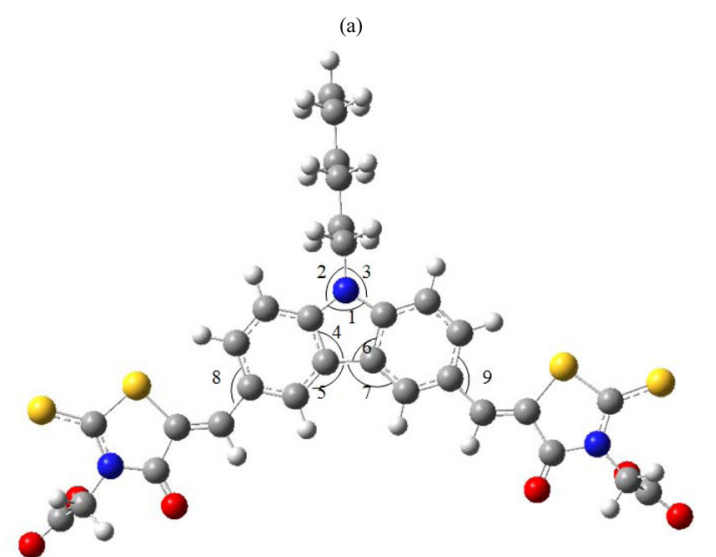

(b)

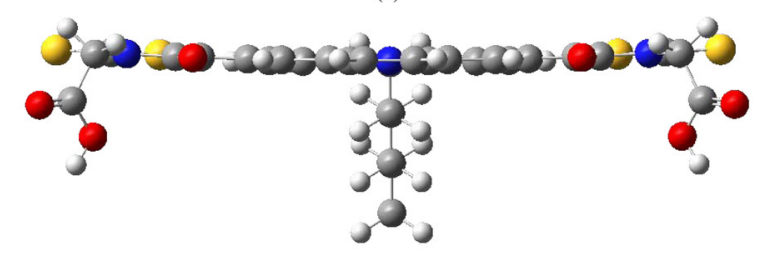

(c)
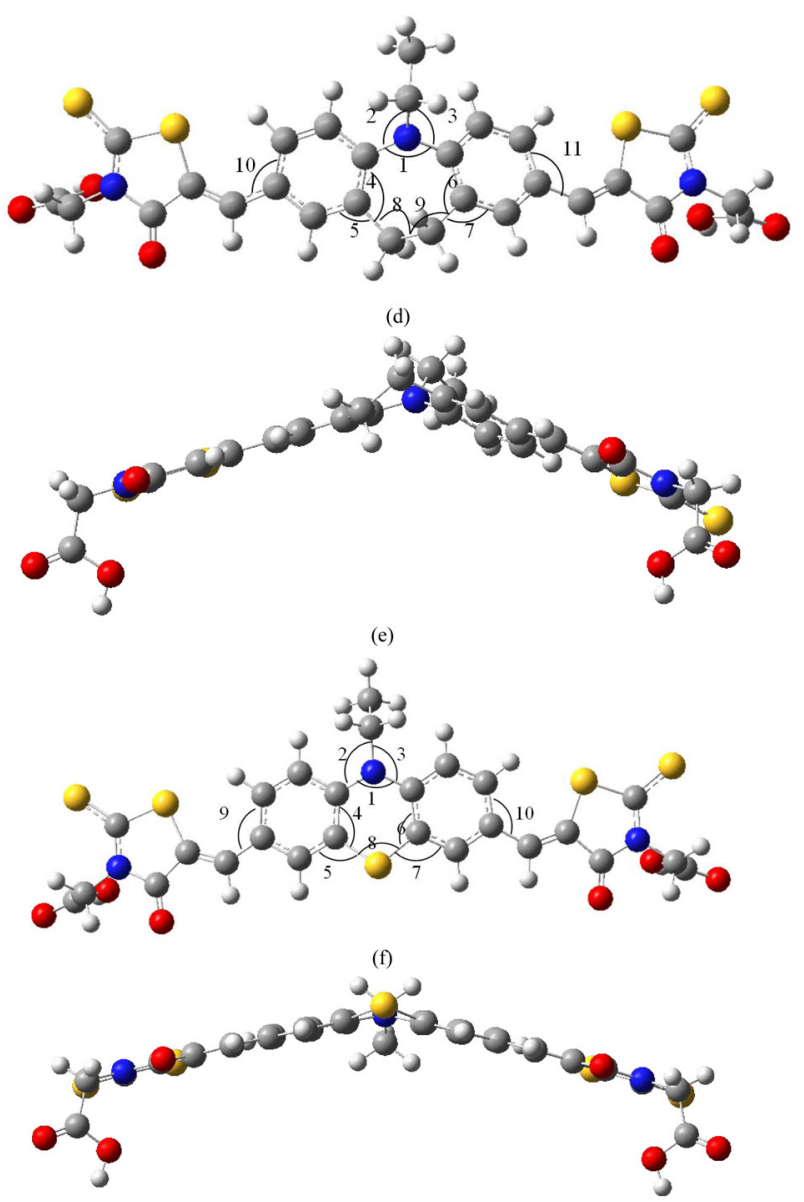

Figure 2. Optimized geometric structures of (a) $\mathbf{S 1}$ top view, (b) $\mathbf{S 1}$ front view, (c) $\mathbf{S} 2$ top view, (d) $\mathbf{S} 2$ front view, (e) $\mathbf{S 3}$ top view and (f) S3 front view.

shown in Figure 3 and the $\lambda_{\max }$ values are listed in Table 2. The absorption spectrum of S2 in DMF exhibits two 
major prominent bands, appearing at 300-400 $\mathrm{nm}$ and at $400-600 \mathrm{~nm}$, respectively. The former is ascribed to a localized aromatic $\pi-\pi^{*}$ transition and the latter is of chargetransfer character between the iminodibenzyl-based donor and the rhodanine-3-acetic acid, ${ }^{31}$ providing efficient charge separation at the excited state. Under similar conditions, the S1 sensitizer had an absorption peak at $450 \mathrm{~nm}$ that was slightly red-shifted relative to the peaks of $\mathbf{S 2}$, implying that the incorporation of the carbazole unit leads to better coplanarity than that achieved by the iminodibenzyl unit.
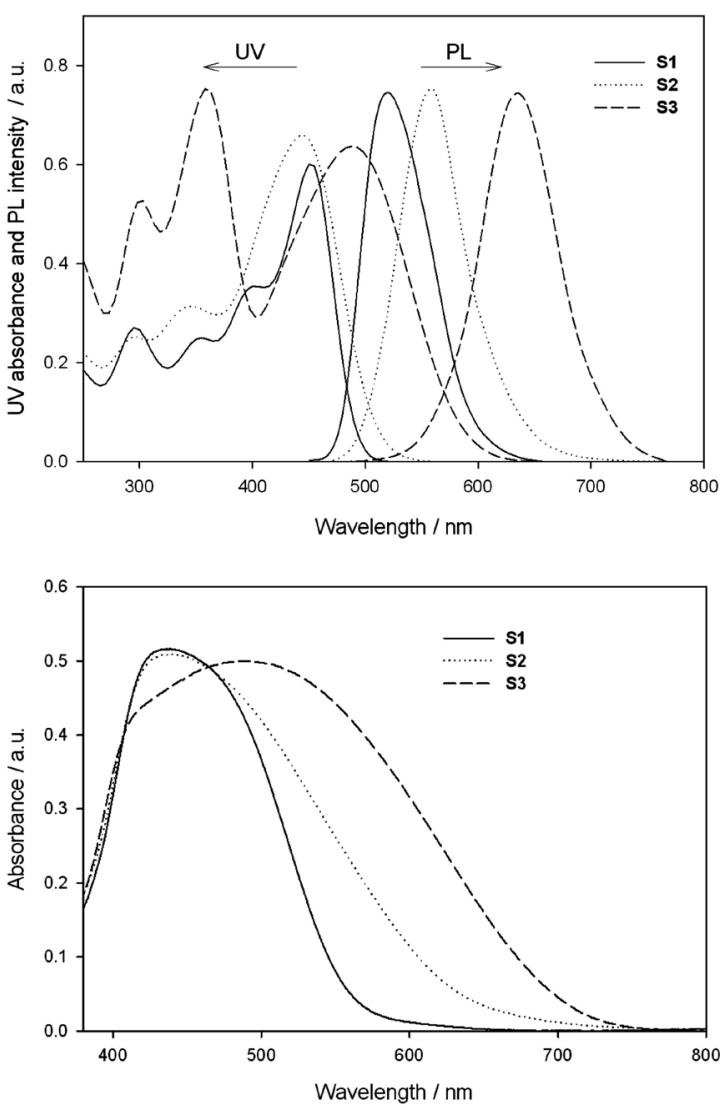

Figure 3. (a) Absorption and emission spectra of $\mathbf{S 1}, \mathbf{S} 2$ and $\mathbf{S 3}$ in DMF $\left(10^{-5} \mathrm{~mol} \mathrm{~L}^{-1}\right), \lambda_{\text {exc }}=420 \mathrm{~nm}$ and (b) absorption spectra of $\mathbf{S 1}, \mathbf{S} 2$ and $\mathbf{S 3}$ absorbed on $\mathrm{TiO}_{2}$ film.

Wherein the phenothiazine unit substitutes the carbazole or iminodibenzyl unit in $\mathbf{S 3}$, the absorption maximum red-shifted to $489 \mathrm{~nm}$. The significant red shift of $\mathbf{S} 3$ relative to $\mathbf{S 1}$ and $\mathbf{S 2}$ is due to stronger intramolecular charge transfer in $\mathbf{S 3}$ as a result of phenothiazine being a stronger electron-donating ring than are carbazole and iminodibenzyl. Red-shifting in the absorption spectra helps utilize solar light. The absorption spectra of S1-S3 on a $\mathrm{TiO}_{2}$ electrode are broader than those in DMF solution. When the $\mathbf{S 1}$ and $\mathbf{S 3}$ sensitizers are adsorbed on the $\mathrm{TiO}_{2}$ electrode, there is a slight blue shift from 450 to $442 \mathrm{~nm}$ and 489 to $488 \mathrm{~nm}$ (Table 2), respectively, implying that dyes adsorbed on the $\mathrm{TiO}_{2}$ surface have partial $\mathrm{H}$-type aggregates. Under similar conditions, the $\mathbf{S 2}$ sensitizer has a slight red shift from 445 to $447 \mathrm{~nm}$ after being adsorbed on the $\mathrm{TiO}_{2}$ electrode. The molar extinction coefficients (ع) of $\mathbf{S 1}, \mathbf{S 2}$ and $\mathbf{S 3}$ are $26360 \mathrm{~L} \mathrm{~mol}^{-1} \mathrm{~cm}^{-1}$ (at $450 \mathrm{~nm}$ ), $24040 \mathrm{~L} \mathrm{~mol}^{-1} \mathrm{~cm}^{-1}$ (at $445 \mathrm{~nm}$ ) and $25480 \mathrm{~L} \mathrm{~mol}^{-1} \mathrm{~cm}^{-1}$ (at $489 \mathrm{~nm}$ ), respectively; larger than that of $\mathrm{Ru}$ organic complex $\left(14200 \mathrm{~L} \mathrm{~mol}^{-1} \mathrm{~cm}^{-1}\right),{ }^{32}$ indicating that they are beneficial to light harvesting.

Figure 3(a) shows the emission spectra of the dyes in DMF solution. The excitation wavelength for emission was the maximum absorption in the visible region. The corresponding data are summarized in Table 2. It can be seen that the maximum emission wavelengths in DMF solution follow the order $\mathbf{S 3}>\mathbf{S 2}>\mathbf{S 1}$. The maximum emission wavelength was red-shifted when iminodibenzyl was substituted by phenothiazine $(558 \mathrm{~nm}$ for $\mathbf{S 2}$ and $635 \mathrm{~nm}$ for $\mathbf{S 3}$ ), but the peak was blue-shifted by introducing a 9-hexylcarbazole moiety as an electron donor (521 nm for S1). S3 exhibited a relatively large Stokes shift, which could be attributed to the geometrically relaxed structure of the phenothiazine center upon excitation. ${ }^{33} \mathrm{~A}$ large Stokes shift is advantageous because it minimizes interference by the excitation light in the measurement of the fluorescence emission.

\section{Electrochemical properties}

To evaluate the thermodynamic allowed electron transfer processes from the excited dye molecule to the conduction band of $\mathrm{TiO}_{2}$, cyclic voltammetry $(\mathrm{CV})$ measurements were performed. The electrochemical behavior of S1-S3 in the anodic direction was irreversible.

Table 2. Absorption and emission properties of $\mathbf{S 1}, \mathbf{S} 2$ and $\mathbf{S 3}$ dyes

\begin{tabular}{|c|c|c|c|c|c|}
\hline \multirow{2}{*}{ Dye } & \multicolumn{2}{|c|}{ Absorption } & \multicolumn{2}{|c|}{ Emission } & \multirow{2}{*}{ Stokes shift ${ }^{\mathrm{a}} / \mathrm{nm}$} \\
\hline & $\lambda_{\mathrm{abs}}{ }^{\mathrm{b}} / \mathrm{nm}$ & $\varepsilon / \mathrm{L} \mathrm{mol}^{-1} \mathrm{~cm}^{-1}\left(\right.$ at $\left.\lambda_{\mathrm{abs}}\right)$ & $\lambda_{\mathrm{abs}}{ }^{\mathrm{b}} / \mathrm{nm}\left(\right.$ on $\left.\mathrm{TiO}_{2}\right)$ & $\lambda_{\mathrm{em}}{ }^{\mathrm{b}} / \mathrm{nm}$ & \\
\hline $\mathbf{S} \mathbf{1}^{\mathrm{b}}$ & $295,355,403,450$ & $26360(450 \mathrm{~nm})$ & 442 & 521 & 71 \\
\hline S2 & $296,346,445$ & $24040(445 \mathrm{~nm})$ & 447 & 558 & 113 \\
\hline S3 & $298,357,489$ & $25480(489 \mathrm{~nm})$ & 488 & 635 & 146 \\
\hline
\end{tabular}

a Stokes shift $=\lambda_{\text {em(solution) }}-\lambda_{\text {abs(solution) }} ;$ babsorption and emission spectra were measured in DMF solution. 
The ground-state oxidation potentials $\left(E_{\mathrm{ox}}\right)$ of the three dyes were measured and the results summarized in Table 3 . The ferrocenium/ferrocene $\left(\mathrm{Fc} / \mathrm{Fc}^{+}\right)$redox couple was used as internal reference. The $\mathrm{E}_{\text {onset(ox) }}$ of $\mathbf{S 3}$ is less positive than those of $\mathbf{S 1}$ and $\mathbf{S 2}$, indicating that the phenothiazine units are much more effective in lowering the ionization potential than are iminodibenzyl and carbazole units.

The ground-state oxidation potentials $E\left(\mathrm{~S}^{+} / \mathrm{S}\right)$ of $\mathbf{S 1}, \mathbf{S 2}$ and $\mathbf{S 3}$, corresponding to the highest occupied molecular orbital (HOMO) level of sensitizers, were estimated to be $0.64,0.62$ and $0.55 \mathrm{~V}$, respectively, vs. the normal hydrogen electrode (NHE). The HOMO levels of S1 and S2 (0.64 and $0.62 \mathrm{~V} v s$. NHE, respectively) are more positive than that of $\mathbf{S 3}(0.55 \mathrm{~V} v s$. NHE), indicating more efficient dye regeneration for $\mathbf{S 1}$ and $\mathbf{S 2}$.

The excited-state oxidation potentials $E\left(\mathrm{~S}^{+} / \mathrm{S}^{*}\right)$, which reflect the lowest occupied molecular orbital (LUMO) level of the sensitizers, play an important role in the electron injection process. The excited-state oxidation potential $E\left(\mathrm{~S}^{+} / \mathrm{S}^{*}\right)$ was calculated using: ${ }^{34}$

$E\left(\mathrm{~S}^{+} / \mathrm{S}^{*}\right)=E\left(\mathrm{~S}^{+} / \mathrm{S}\right)-E_{0-0}$

where $E_{0-0}$ is the zeroth-zeroth transition value obtained from the intersection of the normalized lowest energy absorption peak and highest energy fluorescence peak. The LUMO levels of $\mathbf{S 1}$ and $\mathbf{S 2}(-1.92$ and $-1.85 \mathrm{~V} v s$. NHE, respectively) are more negative than that of $\mathbf{S 3}(-1.63 \mathrm{vs}$. NHE), indicating that $\mathbf{S} \mathbf{1}$ and $\mathbf{S 2}$ dyes have more efficient electron injection.

Figure 4 shows a schematic energy diagram of a DSSC based on dyes attached to a nanocrystalline $\mathrm{TiO}_{2}$ film deposited on conducting fluorine-doped tin oxide (FTO) glass. The oxidation potentials (approximately the HOMO levels) of the dyes range from 0.55 to $0.64 \mathrm{~V} v s$. NHE. These values are more positive than the $\mathrm{I}_{3}^{-} / \mathrm{I}^{-}$redox potential $\left(0.42 \mathrm{~V} v s\right.$. NHE), ${ }^{35}$ indicating that the oxidized dye formed after electron injection into the conduction band of $\mathrm{TiO}_{2}$ thermodynamically accepted electrons from
$\mathrm{I}^{-}$ions in the electrolyte. The LUMO levels of these dyes were estimated from the difference between $E_{\text {ox }}$ and $E_{0-0}$; they are in the range of -1.63 to $-1.92 \mathrm{~V} v s$. NHE, which are more negative than the conduction band edge of $\mathrm{TiO}_{2}$ $\left(-0.5 \mathrm{~V} v s\right.$. NHE) ${ }^{35}$ Provided that an energy gap (between dye $\mathrm{LUMO}$ and $\mathrm{TiO}_{2}$ conduction band (CB)) of $0.2 \mathrm{eV}$ is necessary for efficient electron injection, ${ }^{36}$ the driving force is sufficient for efficient charge injection. Thus, the electron injection process from the excited dye molecule to the $\mathrm{TiO}_{2}$ conduction band and the subsequent dye regeneration are energetically permitted. Such electronic structures thus ensure a favorable exothermic flow of charges throughout the photo-electric conversion. However, in an actual device, molecules have interfaces or other molecules as neighbors, which a consequent modification of electronic structure and molecular conformation implying in differences in the energy levels.

Since energy levels in several cases, such as values obtained using XPS (X-ray photoelectron spectroscopy) or UPS (ultraviolet photoelectron spectroscopy), referring these values to vacuum, we evaluate the ionization potential (IP) and electroaffinity (EA) to realize and control the electrical and optical properties. ${ }^{37-39}$ IP gives a good indication of whether a given p-type dopant is capable of ionizing a compound, whereas EA is important for comprehending the $\mathrm{n}$-type doping process. The positions of the HOMO (IP) levels of $\mathbf{S 1}, \mathbf{S 2}$ and $\mathbf{S 3}$ relative to a vacuum were estimated to be $-5.15,-5.13$ and $-5.06 \mathrm{eV}$, respectively. Similarly, the LUMO (EA) levels of S1, S2 and $\mathbf{S 3}$ relative to a vacuum were estimated to be -2.59 , -2.66 and $-2.88 \mathrm{eV}$, respectively.

\section{Molecular orbital calculations}

To investigate the molecular structure and electron distribution of the organic dyes, the geometries of the organic dyes were optimized using density functional theory (DFT) calculations at a B3LYP/6-31+g (d) level. The isodensity surface plots of frontier orbitals involved in these

Table 3. Electrochemical properties and band gaps of $\mathbf{S 1}, \mathbf{S 2}$ and $\mathbf{S 3}$ dyes

\begin{tabular}{lcccccccc}
\hline Dye & $\begin{array}{c}\mathrm{E}_{\text {onset(ox) }} \\
\text { in DMF }\end{array}$ & $\begin{array}{c}\mathrm{E}_{\text {onset(ox) }} v s . \\
\mathrm{E}_{\mathrm{Foc}}{ }^{a} / \mathrm{V}\end{array}$ & $\begin{array}{c}E\left(\mathrm{~S}^{+} / \mathrm{S}\right)^{\mathrm{b}, \mathrm{d}} v s . \\
\mathrm{NHE} / \mathrm{V}\end{array}$ & $\begin{array}{c}E_{0-0}^{\mathrm{c}} \\
(\mathrm{eV})\end{array}$ & $\begin{array}{c}\text { LUMO } v s . \\
\mathrm{NHE} / \mathrm{eV}\end{array}$ & $\mathrm{E}_{\text {gap }} / \mathrm{V}^{\mathrm{e}}$ & $\begin{array}{c}\text { HOMO (IP) } \\
/ \mathrm{eV}\end{array}$ & $\begin{array}{c}\mathrm{LUMO}(\mathrm{EA})^{\mathrm{g}} \\
/ \mathrm{eV}\end{array}$ \\
\hline S1 & 0.31 & 0.35 & 0.64 & 2.56 & -1.92 & 1.42 & -5.15 & -2.59 \\
S2 & 0.29 & 0.33 & 0.62 & 2.47 & -1.85 & 1.35 & -5.13 & -2.66 \\
S3 & 0.22 & 0.26 & 0.55 & 2.18 & -1.63 & 1.13 & -5.06 & -2.88 \\
\hline
\end{tabular}

${ }^{\mathrm{a}} \mathrm{E}_{\mathrm{FOC}}=-0.04 \mathrm{~V} v s . \mathrm{Ag} / \mathrm{Ag}^{+} ;$b the ground-state oxidation potentials $E\left(\mathrm{~S}^{+} / \mathrm{S}\right)$ were measured in DMF containing $0.1 \mathrm{~mol} \mathrm{~L}^{-1}$ tetrabutylammonium perchlorate as supporting electrolyte using a glassy carbon working electrode, a Pt counter electrode and a $\mathrm{Ag} / \mathrm{Ag}^{+}$reference electrode; cthe $E_{0-0}$ value was estimated

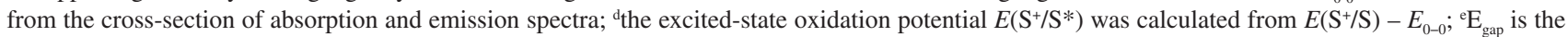
energy gap between $E\left(\mathrm{~S}^{+} / \mathrm{S}^{*}\right)$ of the dye and the conduction band level of $\mathrm{TiO}_{2}\left(-0.5 \mathrm{~V} v s\right.$. NHE); fionization potential: $\mathrm{IP}=-4.8-\left(\mathrm{E}_{\mathrm{onset}(\mathrm{ox})}-\mathrm{E}_{\mathrm{FoC}}\right)$; gelectron affinity: $\mathrm{EA}-E_{0-0}=$ IP. 


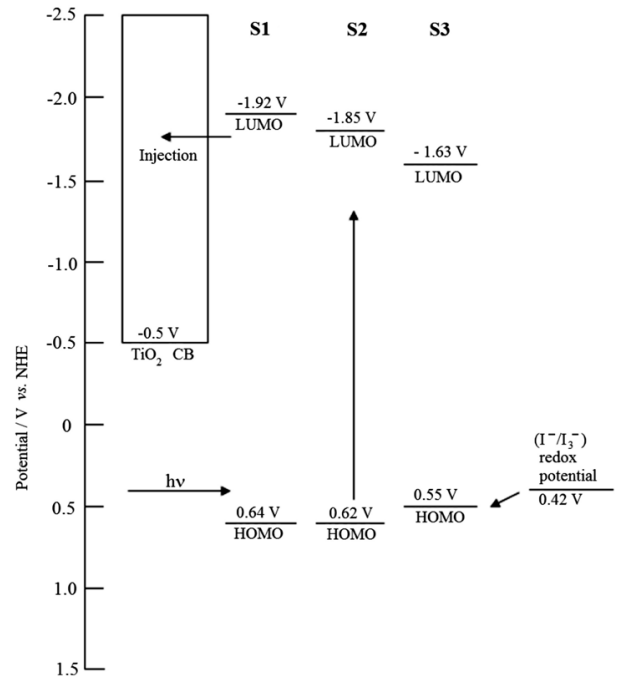

Figure 4. Schematic energy level diagram for a DSSC based on dyes attached to a nanocrystalline $\mathrm{TiO}_{2}$ film deposited on conducting FTO glass.

transitions are shown in Figure 5. The frontier molecular orbitals of S1-S3 reveal that the HOMO levels of the dye molecules are dominated by a $\pi$ orbital contribution from the carbazole, iminodibenzyl and phenothiazine units, with a small contribution from the rhodanine-3-acetic acid moiety and that the HOMO-1 levels are a $\pi$ orbital mainly over the dimethylene bridge and partial rhodanine ring, with a small contribution from the carbazole, iminodibenzyl and phenothiazine units. However, the LUMO levels are largely $\pi^{*}$, with major contributions from the phenyl groups of donors, the dimethylene bridge and the rhodanine ring. The LUMO+1 levels are also $\pi^{*}$ mainly across the dimethylene bridge and rhodanine ring. At the excited state (LUMO) with light illumination for S1-S3 dyes, intramolecular charge transfer occurs, resulting in electron density movement from the donor group to the acceptor groups (rhodanine-3acetic acid group). This orientationally spatial separation of
HOMO and LUMO is ideal for dye sensitized solar cells, as it facilitates rapid interfacial electron injection from the excited dyes to the $\mathrm{TiO}_{2}$ conduction band and slows down the recombination of injected electrons in $\mathrm{TiO}_{2}$ with oxidized sensitizers due to their remoteness.

\section{Photovoltaic performance}

The sensitizers were used for fabricating DSSCs to explore current-voltage characteristics. Figure 6 shows the spectra of incident photon-to-current efficiency (IPCE) for S1-S3-based solar cells. The IPCE values were measured according to the following equation: ${ }^{40}$

$\operatorname{IPCE}(\lambda)=\frac{1240(\mathrm{eV} \mathrm{nm})}{\lambda(\mathrm{nm})} \frac{J_{\mathrm{SC}}\left(\mathrm{mA} \mathrm{cm}^{-2}\right)}{\phi\left(\mathrm{mW} \mathrm{cm}^{-2}\right)}$

where $\lambda$ is the wavelength, short-circuit current $\left(J_{\mathrm{sc}}\right)$ and $\phi$ is the power of the incident radiation per unit area. The IPCE values of dyes as a function of excitation wavelength plots show that the IPCEs of $\mathbf{S 1}, \mathbf{S 2}$ and $\mathbf{S 3}$ are $48-58 \%$ in the spectral range of 450 to $520 \mathrm{~nm}$. The IPCE spectrum covers the whole visible region in the range of $400-750 \mathrm{~nm}$, allowing the DSSC to efficiently convert solar light into electricity.

A typical photocurrent-photovoltage $(I-V)$ curve for cells based on S1-S3 is shown in Figure 7. The detailed photovoltaic parameters are summarized in Table 4 . The solar-energy-to-electricity conversion efficiency $(\eta)$ of the DSSCs is calculated from short-circuit current $\left(J_{\mathrm{sc}}\right)$, the open-circuit photovoltage $\left(V_{\mathrm{oc}}\right)$, the fill factor $(\mathrm{FF})$ and the intensity of the incident light $\left(P_{\text {in }}\right)$ according to the following equation: ${ }^{40}$

$$
\eta=\frac{\left[J_{\mathrm{SC}}\left(\mathrm{mA} \mathrm{cm}^{-2}\right)\right]\left[V_{\mathrm{oc}}(\mathrm{V})\right][\mathrm{FF}]}{P_{\mathrm{nn}}\left(\mathrm{mW} \mathrm{cm}^{-2}\right)}
$$

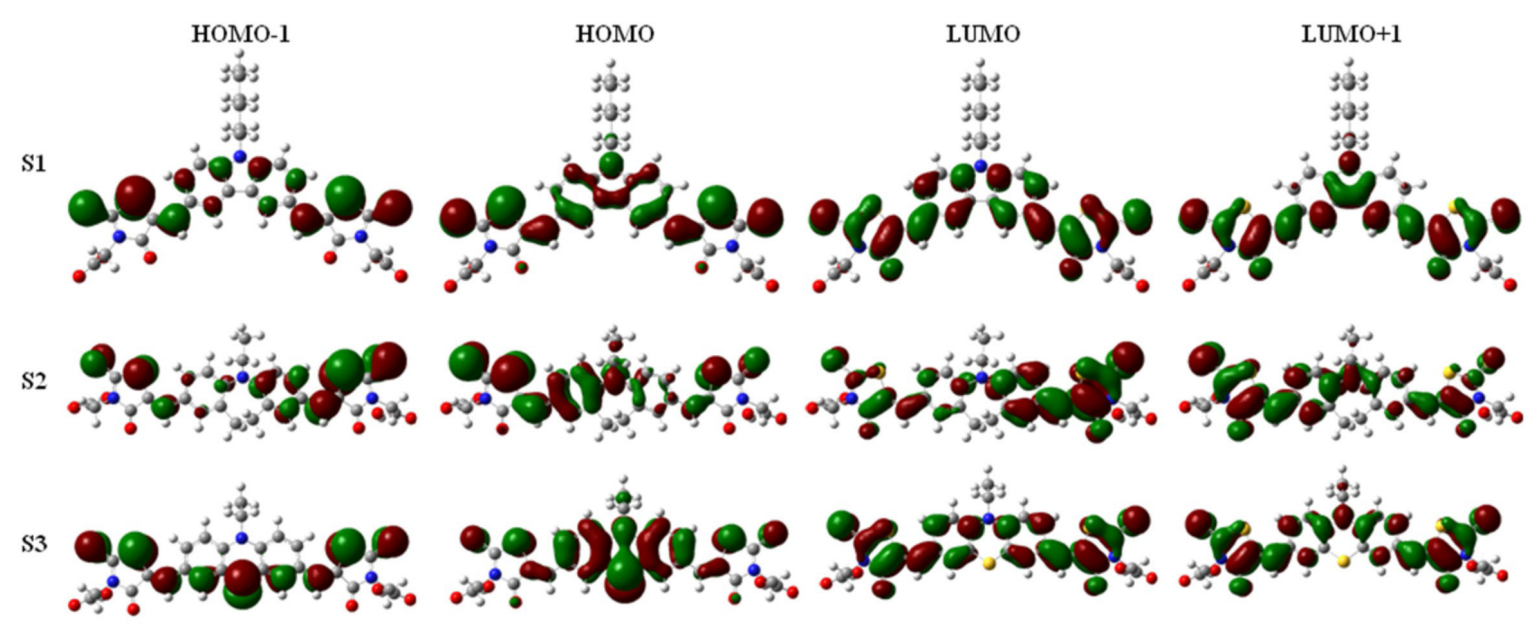

Figure 5. Computed isodensity surfaces of HOMO and LUMO orbitals of S1, S2 and S3. 


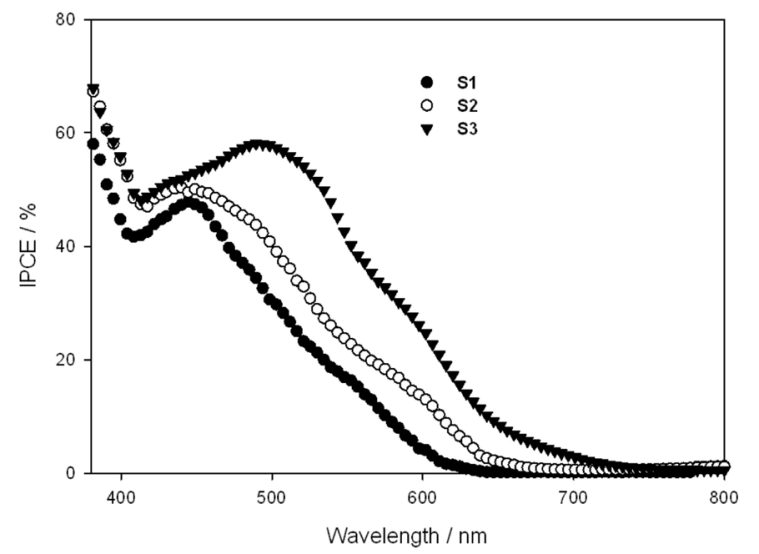

Figure 6. Action spectra of IPCE for DSSCs based on S1, S2 and S3 dyes under the same conditions.

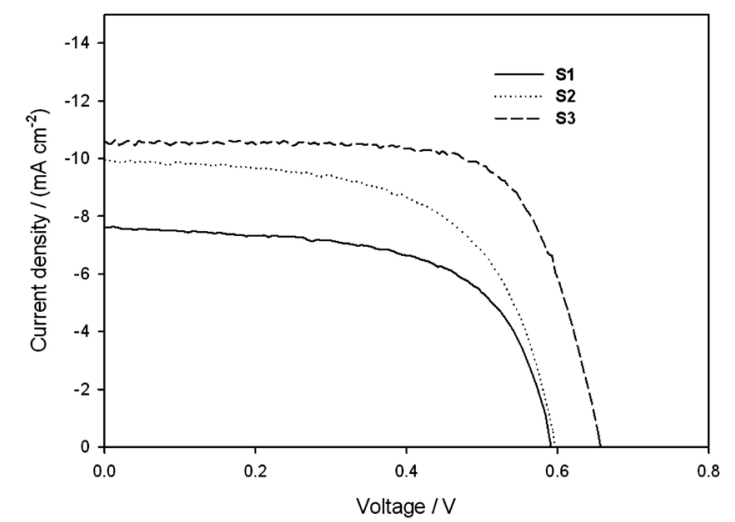

Figure 7. Current density-voltage characteristics for S1, S2 and S3 DSSCs under illumination of simulated solar light (AM 1.5, $100 \mathrm{~mW} \mathrm{~cm}^{-2}$ ).

Table 4. Photovoltaic performances of DSSCs based on S1, S2 and S3 dyes

\begin{tabular}{lcccc}
\hline Dye & $V_{\mathrm{oc}} / \mathrm{V}$ & $J_{\mathrm{sc}} / \mathrm{mA} \mathrm{cm}^{-2}$ & Fill factor $(\mathrm{FF})$ & $\eta / \%$ \\
\hline S1 & 0.589 & 7.61 & 0.63 & 2.81 \\
S2 & 0.597 & 9.95 & 0.61 & 3.59 \\
S3 & 0.658 & 10.60 & 0.7 & 4.91 \\
\hline
\end{tabular}

Measured under irradiation of AM $1.5 \mathrm{G}$ simulated solar light $\left(100 \mathrm{~mW} \mathrm{~cm}^{-2}\right)$ at room temperature, $0.25 \mathrm{~cm}^{2}$ working area; b the concentration of dye is $5 \times 10^{-4} \mathrm{~mol} \mathrm{~L}^{-1}$ in tetrahydrofuran (THF), and $0.6 \mathrm{~mol} \mathrm{~L}^{-1}$ tetrabutylammonium iodide (TBAI), $0.1 \mathrm{~mol} \mathrm{~L}^{-1} \mathrm{LiI}$, $0.05 \mathrm{~mol} \mathrm{~L}^{-1} \mathrm{I}_{2}, 0.6 \mathrm{~mol} \mathrm{~L}^{-1}$ DMPII, and $0.5 \mathrm{~mol} \mathrm{~L}^{-1}$ 4-tert-butylpyridine (TBP) in dry acetonitrile (ACN) as electrolyte.

As demonstrated in Table 4, S1 gives a light-toelectricity conversion efficiency of $2.81 \%$ with a shortcircuit photocurrent density $\left(J_{\mathrm{sc}}\right)$ of $7.61 \mathrm{~mA} \mathrm{~cm}^{-2}$, a $V_{\text {oc }}$ of $0.589 \mathrm{~V}$ and a FF of 0.63 under the standard global AM 1.5 solar condition. Under similar conditions, the photovoltaic parameters $\left(J_{\mathrm{sc}}, V_{\mathrm{oc}}\right.$ and $\left.\eta\right)$ of cells with the $\mathbf{S 2}$ sensitizer are $9.95 \mathrm{~mA} \mathrm{~cm}{ }^{-2}, 0.597 \mathrm{~V}$ and $3.59 \%$, respectively, and those of the $\mathbf{S 3}$ sensitizer are $10.60 \mathrm{~mA} \mathrm{~cm}{ }^{-2}, 0.658 \mathrm{~V}$ and $4.91 \%$, respectively. The efficiency improvement exhibited by the $\mathbf{S 3}$ sensitizer is probably due to the stronger electron-donating ability of the phenothiazine unit when electrons transfer from the phenothiazine unit to the rhodanine-3-acetic acid group, and a possible vectorized photon-induced charge transfer of the phenothiazine unit with respect to electrodes. This character could not only depress the interaction between molecules resulting in the energy quenching of the excited states, but also suppress the $\mathrm{I}_{3}^{-}$ions in the electrolyte to the $\mathrm{TiO}_{2}$ surface that is in favor of higher $V_{\text {oc }}$.

Pathways of photon-to-current conversion in dyesensitized solar cells

Figure 8 shows a schematic representation of a DSSC based on the $\mathbf{S} 2$ photosensitizer. A thin film of electrolyte solution $\left(\mathrm{I}^{-} / \mathrm{I}_{3}^{-}\right.$dissolved in an organic solvent) is sandwiched between the $\mathrm{TiO}_{2}$ electrode and a transparent conducting electrode (counter electrode).

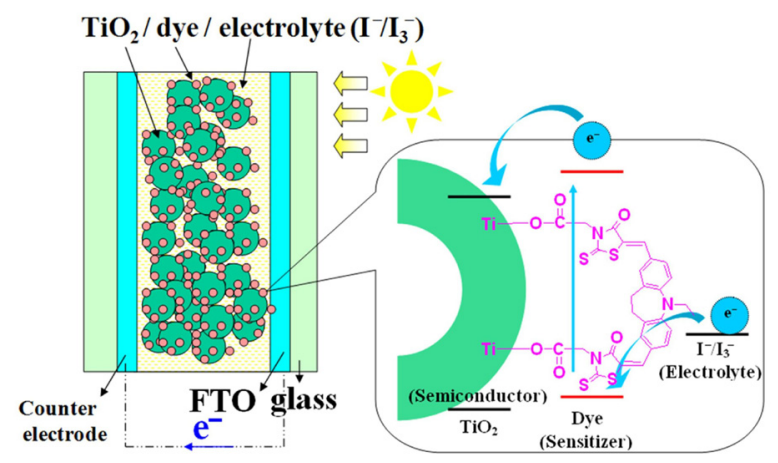

Figure 8. Schematic representation for a DSSC based on the S2 photosensitizer, $\mathrm{I}^{-} / \mathrm{I}_{3}^{-}$redox electrolyte, $\mathrm{TiO}_{2}$ anode and counter cathode.

The general design principle for metal-free organic dyes or sensitizers consists of a donor-acceptorsubstituted $\pi$-conjugated bridge and an anchoring group to the $\mathrm{TiO}_{2}$ which is attached to the side of the acceptor (Figure 9). Light-harvesting dyes absorb solar radiation incident on them, which results in their excitation. The excited molecules pass their energy by transferring electrons onto a nanocrystalline $\mathrm{TiO}_{2}$ substrate onto which they are adsorbed. The injected electrons in

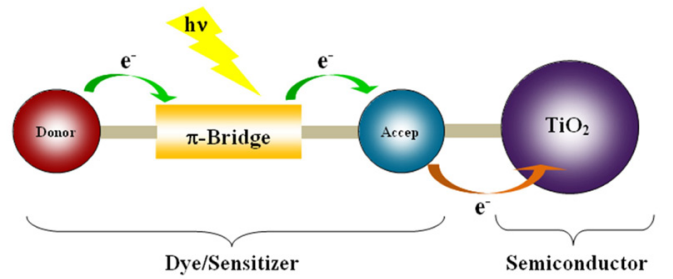

Figure 9. Design principle of organic dyes for $\mathrm{TiO}_{2}$ photoanodes in DSSCs. 
the conduction band of $\mathrm{TiO}_{2}$ are transported toward the counter electrode through the external load. At the counter electrode, a redox couple is utilized (usually iodide-triiodide) to regenerate the dye so the process can be repeated.

\section{Conclusion}

We synthesized three di-anchoring organic dyes containing carbazole, iminodibenzyl and phenothiazine units, respectively, as donors to compare and study their optical, electrochemical and photovoltaic properties. The electron-donating groups of organic sensitizers show different interactions on $\mathrm{TiO}_{2}$ surface. The LUMO values of $\mathbf{S 1}(-1.92 \mathrm{~V}), \mathbf{S 2}(-1.85 \mathrm{~V})$ and $\mathbf{S 3}(-1.63 \mathrm{~V})$ are more than $0.2 \mathrm{eV}$ negative than the conduction band edge of $\mathrm{TiO}_{2}(-0.5 \mathrm{~V} v s$. NHE), implying that the driving force is sufficient for efficient charge injection. The HOMO values of $\mathbf{S 1}(0.64 \mathrm{~V}), \mathbf{S 2}(0.62 \mathrm{~V})$ and $\mathbf{S 3}(0.55 \mathrm{~V})$ are sufficiently more positive than the $\mathrm{I}_{3}^{-} / \mathrm{I}^{-}$redox potential (0.42 V vs. NHE). DSSCs based on the $\mathbf{S 3}$ dye showed the best photovoltaic performance: a maximum IPCE of $58 \%$, a short-circuit photocurrent density $\left(J_{\mathrm{sc}}\right)$ of $10.60 \mathrm{~mA} \mathrm{~cm}^{-2}$, a $V_{\text {oc }}$ of $0.658 \mathrm{~V}$ and a FF of 0.7 , corresponding to an overall conversion efficiency of $4.91 \%$ under $100 \mathrm{~mW} \mathrm{~cm}^{-2}$ irradiation. The proposed di-anchoring organic dyes are promising candidates for DSSCs.

\section{Supplementary Information}

Supplementary data are available free of charge as PDF file at http://jbcs.sbq.org.br.

\section{Acknowledgement}

The authors would like to thank the National Science Council of the Republic of China for financially supporting this project.

\section{References}

1. Shirota, Y.; J. Mater. Chem. 2005, 15, 75.

2. Aquino, J. M.; Rocha-Filho, R. C.; Bocchi, N.; Biaggio, S. R.; J. Braz. Chem. Soc. 2010, 21, 324.

3. Ensafi, A. A.; Hajian, R.; Ebrahimi, S.; J. Braz. Chem. Soc. 2009, 20, 266.

4. Wu, T. Y.; Wang, H. C.; Su, S. G.; Gung, S. T.; Lin, M. W.; Lin, C. B.; J. Chin. Chem. Soc. 2010, 57, 44.

5. Peralta-Zamora, P.; J. Braz. Chem. Soc. 2010, 21, 1621.

6. Paprocki, A.; dos Santos, H. S.; Hammerschitt, M. E.; Pires, M.; Azevedo, C. M. N.; J. Braz. Chem. Soc. 2010, 21, 452.
7. Ferreira, J.; Girotto, E. M.; J. Braz. Chem. Soc. 2010, 21, 312.

8. Kulkarni, A. P.; Tonzola, C. J.; Babel, A.; Jenekhe, S. A.; Chem. Mater. 2004, 16, 4556.

9. Wu, T.-Y.; Lee, N.-C.; Chen, Y.; Synth. Met. 2003, 139, 263.

10. Wu, T.-Y.; Tsao, M. H.; Chen, F. L.; Su, S. G.; Chang, C. W.; Wang, H. P.; Lin, Y. C.; Ou-Yang, W.-C.; Sun, I. W.; Int. J. Mol. Sci. 2010, 11, 329.

11. Chen, Z.; Li, F.; Huang, C.; Curr. Org. Chem. 2007, 11, 1241.

12. Yahagida, S.; Senadeera, G. K. R.; Nakamura, K.; Kitamura, T.; Wada, Y.; J. Photoch. Photobio. A 2004, 166, 75.

13. Hara, K.; Tachibana, Y.; Ohga, Y.; Shinpo, A.; Suga, S.; Sayama, K.; Sugihara, H.; Arakawa, H.; Sol. Energ. Mat. Sol. C. 2003, $77,89$.

14. Horiuchi, T.; Miura, H.; Uchida, S.; Chem. Commun. 2003, 3036.

15. Sayama, K.; Tsukagoshi, S.; Hara, K.; Ohga, Y.; Shinpou, A.; Abe, Y.; Suga, S.; Arakawa, H.; J. Phys. Chem. B 2002, 106, 1363.

16. Yao, Q.-H.; Shan, L.; Li, F.-Y.; Yin, D.-D.; Huang, C.-H.; New J. Chem. 2003, 27, 1277.

17. Jung, I.; Lee, J. K.; Song, K. H.; Song, K.; Kang, S. O.; Ko, J.; J. Org. Chem. 2007, 72, 3652.

18. Alam, M. M.; Jeneke, S. A.; Chem. Mater. 2002, 14, 4775.

19. Babel, A.; Jenekhe, S. A.; J. Phys. Chem. B 2003, 107, 1749.

20. Fungo, F.; Jenekhe, S. A.; Bard, A. J.; Chem. Mater. 2003, 15, 1264.

21. Sapp, S. A.; Sotzing, G. A.; Reynolds, J. R.; Chem. Mater. 1998, 10, 2101; Fungo, F.; Jenekhe, S. A.; Bard, A.; J. Chem. Mater. 2004, 15, 1264.

22. Wu, T.-Y.; Chen, Y.; J. Polym. Sci. Pol. Chem. 2002, 40, 4452.

23. Wu, T.-Y.; Tsao, M. H.; Chen, F. L.; Su, S. G.; Chang, C. W.; Wang, H. P.; Lin, Y. C.; Sun, I. W.; J. Iran. Chem. Soc. 2010, 7, 707.

24. Jang, S. Y.; Seshadri, V.; Khil, M. S.; Kumar, A.; Marquez, M.; Mather, P. T.; Sotzing, G. A.; Adv. Mater. 2005, 17, 2177.

25. Wang, P.; Zakeeruddin, S. M.; Comte, P.; Charvet, R.; HumphryBaker, R.; Grätzel, M.; J. Phys. Chem. B 2003, 107, 14336.

26. Matsui, M.; Hashimoto, Y.; Funabiki, K.; Jin, J.; Yoshida, T.; Minoura, H.; Synth. Met. 2005, 148, 147.

27. Frisch, M. J.; Trucks, G. W.; Schlegel, H. B.; Scuseria, G. E.; Robb, M. A.; Cheeseman, Jr. J. R.; Montgomery, J. A.; Vreven, T.; Kudin, K. N.; Burant, J. C.; Millam, J. M.; Iyengar, S. S.; Tomasi, J.; Barone, V.; Mennucci, B.; Cossi, M.; Scalmani, G.; Rega, N.; Petersson, G. A.; Nakatsuji, H.; Hada, M.; Ehara, M.; Toyota, K.; Fukuda, R.; Hasegawa, J.; Ishida, M.; Nakajima, T.; Honda, Y.; Kitao, O.; Nakai, H.; Klene, M.; Li, X.; Knox, J. E.; Hratchian, H. P.; Cross, J. B.; Adamo, C.; Jaramillo, J.; Gomperts, R.; Stratmann, R. E.; Yazyev, O.; Austin, A. J.; Cammi, R.; Pomelli, C.; Ochterski, J. W.; Ayala, P. Y.; Morokuma, K.; Voth, G. A.; Salvador, P.; Dannenberg, J. J.; Zakrzewski, V. G.; Dapprich, S.; Daniels, A. D.; Strain, M. C.; 
Farkas, O.; Malick, D. K.; Rabuck, A. D.; Raghavachari, K.; Foresman, J. B.; Ortiz, J. V.; Cui, Q.; Baboul, A. G.; Clifford, S.; Cioslowski, J.; Stefanov, B. B.; Liu, G.; Liashenko, A.; Piskorz, P.; Komaromi, I.; Martin, R. L.; Fox, D. J.; Keith, T.; Al-Laham, M. A.; Peng, C. Y.; Nanayakkara, A.; Challacombe, M.; Gill, P. M. W.; Johnson, B.; Chen, W.; Wong, M. W.; Gonzalez, C.; Pople, J. A.; Gaussian 03, Revision C.01, Gaussian, Inc.: Wallingford, CT 2004.

28. Chen, Y.; Wu, T.-Y.; Polymer 2001, 42, 9895.

29. Oelschlager, H.; Peters, H. J.; Arch. Pharm. 1987, 320, 379.

30. McDowell, J. J. H.; Acta Crystallogr. 1976, B32, 5.

31. Liang, M.; Xu, W.; Cai, F.; Chen, P.; Peng, B.; Chen, J.; Li, Z.; J. Phys. Chem. C 2007, 111, 4465.

32. Nazeeruddin, M. K.; Kay, A.; Rodicio, I.; Humpbry-Baker, R.; Miiller, E.; Liska, P.; Vlachopoulos, N.; Grätzel, M.; J. Am. Chem. Soc. 1993, 115, 6382.
33. Lai, R. Y.; Fabrizio, E. F.; Lu, L.; Jenekhe, S. A.; Bard, A. J.; J. Am. Chem. Soc. 2001, 123, 9112.

34. Chen, K. F.; Hsu, Y. C.; Wu, Q. Y.; Yeh, M. C. P.; Sun, S. S.; Org. Lett. 2009, 11, 377.

35. Hagfeldt, A.; Grätzel, M.; Chem. Rev. 1995, 95, 49.

36. Ito, S.; Zakeeruddin, S. M.; Humphry-Baker, R.; Liska, P.; Charvet, R.; Comte, P.; Nazeeruddin, M. K.; Péchy, P.; Takata, M.; Miura, H.; Uchida, S.; Grätzel, M.; Adv. Mater. 2006, 18, 1202.

37. Micaroni, L.; Nart, F. C.; Hümmelgen, I. A.; J. Solid State Electrochem. 2002, 7, 55.

38. Wu, T.-Y.; Chen, Y.; J. Polym. Sci. Pol. Chem. 2002, 40, 3847.

39. Wu, T.-Y.; Chen, Y.; J. Polym. Sci. Pol. Chem. 2002, 40, 4570.

40. Boschloo, G.; Hagfeldt, A.; J. Phys. Chem. B 2005, 109, 12093.

Submitted: June 6, 2010

Published online: February 17, 2011 


\title{
Synthesis, Characterization and Photovoltaic Properties of Di-Anchoring Organic Dyes
}

\author{
Tzi-Yi Wu, ${ }^{a, b}$ Ming-Hsiu Tsao, ${ }^{a}$ Shyh-Gang Su, ${ }^{a}$ H. Paul Wang, ${ }^{c, d}$ Yuan-Chung Lin, ${ }^{e}$ \\ Fu-Lin Chen, ${ }^{a}$ Cheng-Wen Chang ${ }^{a}$ and I-Wen Sun ${ }^{*, a, c}$ \\ ${ }^{a}$ Department of Chemistry, ${ }^{c}$ Sustainable Environment Research Center and ${ }^{d}$ Department of \\ Environmental Engineering, National Cheng Kung University, Tainan 701, Taiwan \\ ${ }^{b}$ Department of Polymer Materials, Kun Shan University, Tainan 71003, Taiwan \\ eInstitute of Environmental Engineering, National Sun Yat-Sen University, Kaohsiung 804, Taiwan
}

Synthetic procedure of carbazole, iminodibenzy and phenothiazine-containing dyes (S1-S3)

\section{$N$-hexylcarbazole $(2 a)$}

To a $250 \mathrm{~mL}$ two necked flask was added with carbazole (16.72 g, $100 \mathrm{mmol}), 100 \mathrm{~mL}$ DMF and potassium tert-butoxide (12.4 g, $110 \mathrm{mmol})$. After stirring for $30 \mathrm{~min}$, the mixture was added with $N$-bromohexane $(17.34 \mathrm{~g}, 105$ mmol) and allowed to reflux overnight. Pouring it into a large amount of water precipitated 9-hexylcarbazole, which were collected by filtration and then recrystallized twice in methanol. The yield was $71 \%\left(\mathrm{mp} 53^{\circ} \mathrm{C}\right) .{ }^{1} \mathrm{H} \mathrm{NMR}\left(\mathrm{CDCl}_{3}\right)$, $\delta$ (ppm): 8.13-8.10 (d, 2H), 7.50-7.40 (m, 4H), 7.26-7.21 $(\mathrm{m}, 2 \mathrm{H}), 4.31(\mathrm{t}, J 7.0 \mathrm{~Hz}, 2 \mathrm{H}), 1.88$ (quintet, $J 5.4 \mathrm{~Hz}, 2 \mathrm{H}$ ), $1.39(\mathrm{~m}, 2 \mathrm{H}), 1.31(\mathrm{~m}, 4 \mathrm{H}), 0.88(\mathrm{t}, J 3.3 \mathrm{~Hz}, 3 \mathrm{H})$. Elemental analysis calculated (\%) for $\mathrm{C}_{18} \mathrm{H}_{21} \mathrm{~N}: \mathrm{C}, 86.01 \% ; \mathrm{H}, 8.42 \%$; N, 5.57\%. Found: C, $85.96 \%$; H, 8.40\%; N, 5.55\%.

\section{9-Hexylcarbazole-3,6-dicarbaldehyde (4a)}

To a $50 \mathrm{~mL}$ glass reactor were added with imidazole $(0.718 \mathrm{~g}, 10.5 \mathrm{mmol})$ and $10 \mathrm{~mL}$ acetonitrile. The mixture were added under stirring with trifluoroacetic anhydride $(5.775 \mathrm{~g}, 27.5 \mathrm{mmol})$ within $5 \mathrm{~min}$, treated dropwise with 9-hexylcarbazole (2a: $1.257 \mathrm{~g}, 5 \mathrm{mmol}$ ) and then refluxed for $4 \mathrm{~h}$. After adjusting $\mathrm{pH}>7$ with saturated aqueous solution of $\mathrm{Na}_{2} \mathrm{CO}_{3}$, the appearing precipitates were isolated by filtration and washed with water to give a precipitate. The precipitate was dissolved in $\mathrm{CH}_{2} \mathrm{Cl}_{2}$, washed with saturated aqueous $\mathrm{NaHCO}_{3}$, dried over anhydrous $\mathrm{MgSO}_{4}$ and the solvent was removed under reduced pressure to afford 3,6-bis(1,3bistrifluoracetyl-4,5-dihydroimidazole-2-yl)-9-hexylcarbazole

*e-mail: iwsun@mail.ncku.edu.tw (3a: $3.55 \mathrm{~g}, 92 \%$ ), which was used for the next step without further purification. To a $250 \mathrm{~mL}$ glass reactor were added with 3a $(6.2 \mathrm{~g}, 8 \mathrm{mmol}), 148 \mathrm{~mL}$ acetonitrile and $77 \mathrm{~mL}$ $1.9 \mathrm{~mol} \mathrm{~L}^{-1} \mathrm{HCl}$. The mixture was refluxed for $3 \mathrm{~h}$ and was extracted with ethyl ether after cooling and neutralization. The crude product obtained by removing ethyl ether were purified by column chromatography (silica gel, $60-200 \mathrm{~mm}$, neutrality; $n$-hexane/ethyl acetate $=4 / 1)$ to give $\mathbf{4 a}(1.75 \mathrm{~g}$, $\left.71 \%, \mathrm{mp} 143{ }^{\circ} \mathrm{C}\right) .{ }^{1} \mathrm{H}$ NMR $\left(\mathrm{CDCl}_{3}, \mathrm{ppm}\right): \delta 10.04(\mathrm{~s}, 2 \mathrm{H})$, $8.83(\mathrm{~s}, 2 \mathrm{H}), 8.01(\mathrm{~d}, 2 \mathrm{H}), 7.80(\mathrm{~d}, 2 \mathrm{H}), 4.46(\mathrm{t}, 2 \mathrm{H}), 1.69$ $(\mathrm{m}, 2 \mathrm{H}), 1.16(\mathrm{~m}, 6 \mathrm{H}), 0.73(\mathrm{t}, 3 \mathrm{H})$. Elemental analysis calculated (\%) for $\mathrm{C}_{20} \mathrm{H}_{21} \mathrm{NO}_{2}$ : C, 78.15; H, 6.89; N, 4.56. Found: C, 77.98; H, 6.81; N, 4.65.

5,5'-(9-Hexyl-carbazole-3,6-diyl)bis(methan-1-yl-1-ylidene) bis(4-oxo-2-thioxothiazolidin-3-yl-5-ylidene)diacetic acid (S1)

To a stirred $4 \mathbf{a}(0.615 \mathrm{~g}, 2 \mathrm{mmol})$ in $\mathrm{CH}_{3} \mathrm{COOH}(30 \mathrm{~mL})$ were added rhodanine-3-acetic acid $(0.794 \mathrm{~g}, 4.15 \mathrm{mmol})$ and ammonium acetate $(0.125 \mathrm{~g}, 1.625 \mathrm{mmol})$. The mixture was heated to $120^{\circ} \mathrm{C}$ and the reaction was continued for $2 \mathrm{~h}$ at the temperature. Then the reaction mixture was allowed to cool to room temperature. The solid was collected by filtration and washed with water thoroughly. After drying in air, the crude product was purified by column chromatography on silica gel with $\mathrm{CH}_{2} \mathrm{Cl}_{2} /$ methanol $(10: 1, \mathrm{v} / \mathrm{v})$ as eluant to give $\mathbf{S 1}$ in $93 \%$ yield, $\mathrm{mp}>200^{\circ} \mathrm{C}$. ${ }^{1} \mathrm{H}$ NMR (DMSO- $d_{6}$ ), $\delta$ (ppm): 8.55 (s, 2H, $\left.-\mathrm{C} \underline{\mathrm{H}}=\right), 8.03$ (s, $2 \mathrm{H}$, aromatic hydrogen), 7.84 (d, $2 \mathrm{H}$, aromatic hydrogen), $7.76(\mathrm{~d}, 2 \mathrm{H}$, aromatic hydrogen $), 4.76\left(\mathrm{~s}, 4 \mathrm{H}, \mathrm{O}=\mathrm{C}-\mathrm{CH}_{2}-\mathrm{N}\right)$, 4.47 (t, 2H, N-C $\left.\underline{H}_{2}-\right), 1.79\left(\mathrm{~m}, 2 \mathrm{H}, \mathrm{N}-\mathrm{CH}_{2}-\mathrm{CH}_{2}-\right), 1.26$ (m, $\left.6 \mathrm{H}, \mathrm{N}-\mathrm{CH}_{2}-\mathrm{CH}_{2}-\underline{\mathrm{C}}_{2}-\underline{\mathrm{C}}_{2}-\mathrm{C}_{2}-\mathrm{CH}_{3}\right), 0.80$ (t, $3 \mathrm{H}$, $\left.\mathrm{N}-\mathrm{CH}_{2}-\mathrm{CH}_{2}-\mathrm{CH}_{2}-\mathrm{CH}_{2}-\mathrm{CH}_{2}-\mathrm{CH}_{3}\right)$. Elemental analysis 
calculated (\%) for $\mathrm{C}_{30} \mathrm{H}_{27} \mathrm{~N}_{3} \mathrm{O}_{6} \mathrm{~S}_{4}: \mathrm{C}, 55.11 \% ; \mathrm{H}, 4.16 \%$; $\mathrm{N}, 6.43 \%$. Found: C, $54.92 \%$; H, 4.12\%; N, 6.31\%.

\section{1-Ethyl-iminodibenzyl (2b)}

Iminodibenzyl (1b: $6.834 \mathrm{~g}, 35 \mathrm{mmol})$, iodoethane $(5.93 \mathrm{~g}, 38 \mathrm{mmol})$ and $80 \mathrm{~mL}$ of DMF were added to a 50 $\mathrm{mL}$ two-necked glass reactor. The solution was warmed to $75{ }^{\circ} \mathrm{C}$, treated portionwise with potassium tert-butoxide $(4.264 \mathrm{~g}, 38 \mathrm{mmol})$ and then refluxed for $24 \mathrm{~h}$. After 150 $\mathrm{mL}$ of water was added, the mixture was extracted with chloroform $(75 \mathrm{~mL})$. Crude oils obtained by removing the solvent were purified by column chromatography (silica gels, $n$-hexane/ethyl acetate: $20 / 1$ as eluent) to give $\mathbf{2 b}$ as a white solid $\left(4.76 \mathrm{~g}, 61 \%\right.$, mp $\left.54^{\circ} \mathrm{C}\right) .{ }^{1} \mathrm{H} \mathrm{NMR}\left(\mathrm{CDCl}_{3}\right), \delta$ (ppm): $1.16\left(\mathrm{t}, 3 \mathrm{H}, \mathrm{CH}_{3}\right), 3.17\left(\mathrm{~m}, 4 \mathrm{H}, \mathrm{CH}_{2}\right), 3.80\left(\mathrm{~m}, 2 \mathrm{H}, \mathrm{CH}_{2}\right), 6.92$ (m, 2H, ar), 7.12 (m, 6H, ar). Elemental analysis calculated (\%) for $\mathrm{C}_{16} \mathrm{H}_{17} \mathrm{~N}$ : C, $86.05 \% ; \mathrm{H}, 7.67 \%$;, $6.27 \%$. Found: $\mathrm{C}, 85.96 \% ; \mathrm{H}, 7.73 \% ; \mathrm{N}, 6.20 \%$.

\section{1-Ethyl-3,8-diformyliminodibenzyl (4b)}

To a $50 \mathrm{~mL}$ glass reactor were added with imidazole $(0.718 \mathrm{~g}, 10.5 \mathrm{mmol})$ and $10 \mathrm{~mL}$ acetonitrile. The mixture were added under stirring with trifluoroacetic anhydride $(5.775 \mathrm{~g}, 27.5 \mathrm{mmol})$ within $5 \mathrm{~min}$, treated dropwise with 11-ethyl-iminodibenzyl (2b: $1.117 \mathrm{~g}, 5 \mathrm{mmol})$ and then refluxed for $4 \mathrm{~h}$. After adjusting $\mathrm{pH}>7$ with saturated aqueous solution of $\mathrm{Na}_{2} \mathrm{CO}_{3}$, the appearing precipitates were isolated by filtration and washed with water to give a precipitate. The precipitate was dissolved in $\mathrm{CH}_{2} \mathrm{Cl}_{2}$, washed with saturated aqueous $\mathrm{NaHCO}_{3}$, dried over anhydrous $\mathrm{MgSO}_{4}$ and the solvent was removed under reduced pressure to afford 3,8-bis(1,3-bis-trifluoracetyl-4,5-dihydroimidazole-2-yl)11-ethyliminodibenzyl (3b: $3.35 \mathrm{~g}, 90 \%$ ), which was used for the next step without further purification. To a $250 \mathrm{~mL}$ glass reactor were added with $\mathbf{3 b}(5.95 \mathrm{~g}, 8 \mathrm{mmol}), 148 \mathrm{~mL}$ acetonitrile and $77 \mathrm{~mL} 1.9 \mathrm{~mol} \mathrm{~L}^{-1} \mathrm{HCl}$. The mixture was refluxed for $3 \mathrm{~h}$ and was extracted with ethyl ether after cooling and neutralization. The crude products obtained by removing ethyl ether were purified by column chromatography (silica gel $; n$-hexane/ethyl acetate $=4 / 1)$ to give $4 \mathbf{b}(1.77 \mathrm{~g}, 79 \%, \mathrm{mp}$ $\left.96{ }^{\circ} \mathrm{C}\right) .{ }^{1} \mathrm{H}$ NMR (acetone- $\left.d_{6}, \mathrm{ppm}\right): \delta 9.72(\mathrm{~s}, 2 \mathrm{H},-\mathrm{C} \underline{\mathrm{HO}})$, 7.54 (d, J 7.4 Hz, 2H), 7.48 (s, 2H), 7.09 (d, J $7.3 \mathrm{~Hz}, 2 \mathrm{H})$, $3.73(\mathrm{t}, 2 \mathrm{H}), 3.05$ (s, 4H), 1.07 (t, J $3.3 \mathrm{~Hz}, 3 \mathrm{H})$. Elemental analysis calculated (\%) for $\mathrm{C}_{18} \mathrm{H}_{17} \mathrm{NO}_{2}: \mathrm{C}, 77.40 ; \mathrm{H}, 6.13$; N, 5.01. Found: C, 77.41; H, 6.16; N, 4.96.

5,5'-(11-Ethyl-iminodibenzyl-3,8-diyl)bis(methan-1-yl-1ylidene)bis(4-oxo-2-thioxothiazolidin-3-yl-5-ylidene)diacetic acid (S2)

To a stirred $4 \mathbf{b}(0.558 \mathrm{~g}, 2 \mathrm{mmol})$ in $\mathrm{CH}_{3} \mathrm{COOH}(30 \mathrm{~mL})$ were added rhodanine-3-acetic acid $(0.794 \mathrm{~g}, 4.15 \mathrm{mmol})$ and ammonium acetate $(0.125 \mathrm{~g}, 1.625 \mathrm{mmol})$. The mixture was heated to $120^{\circ} \mathrm{C}$ and the reaction was continued for $2 \mathrm{~h}$ at the temperature. Then the reaction mixture was allowed to cool to room temperature. The solid was collected by filtration and washed with water thoroughly. After drying in air, the crude product was purified by column chromatography on silica gel with $\mathrm{CH}_{2} \mathrm{Cl}_{2} /$ methanol $(10: 1, \mathrm{v} / \mathrm{v})$ as eluent to give $\mathbf{S 2}$ in $83 \%$ yield, $\mathrm{mp}>200^{\circ} \mathrm{C}$. ${ }^{1} \mathrm{H}$ NMR (DMSO- $\left.d_{6}\right), \delta$ (ppm): 7.79 (s, 2H, $-\mathrm{CH}=$ and aromatic hydrogen), 7.50 (m, $4 \mathrm{H}$, aromatic hydrogen), 7.36 (d, $2 \mathrm{H}$, aromatic hydrogen), $4.73\left(\mathrm{~s}, 4 \mathrm{H}, \mathrm{O}=\mathrm{C}-\underline{\mathrm{C}}_{2}-\mathrm{N}\right)$, 3.94 (q, 2H, N-C $\left.\underline{H}_{2}-\right), 3.18$ (t, 4H, - $\left.\mathrm{C}_{2}-\underline{\mathrm{C}}_{2}-\right), 1.19$ (t, $3 \mathrm{H}, \mathrm{N}-\mathrm{CH}_{2}-\mathrm{CH}_{3}$ ). Elemental analysis calculated (\%) for $\mathrm{C}_{28} \mathrm{H}_{23} \mathrm{~N}_{3} \mathrm{O}_{6} \mathrm{~S}_{4}: \mathrm{C}, 53.74 \% ; \mathrm{H}, 3.70 \%$;, $6.72 \%$. Found: C, $53.51 \%$; H, 3.62\%; N, 6.58\%.

\section{0-Ethyl-phenothiazine (2c)}

Phenothiazine (1c: $11.94 \mathrm{~g}, 60 \mathrm{mmol}$ ), iodoethane $(10.92 \mathrm{~g}, 70 \mathrm{mmol})$ and $80 \mathrm{~mL}$ of DMF were added to a $50 \mathrm{~mL}$ two-necked glass reactor. The solution was warmed to $75^{\circ} \mathrm{C}$, treated portionwise with potassium tert-butoxide $(7.86 \mathrm{~g}, 70 \mathrm{mmol}$ ) and then refluxed for $24 \mathrm{~h}$. After $150 \mathrm{~mL}$ of water was added, the mixture was extracted with chloroform $(75 \mathrm{~mL})$. Crude product obtained by removing the solvent were purified by column chromatography (silica gels, $n$-hexane/ethyl acetate: $20 / 1$ as eluent) to give $\mathbf{2 c}$ as a white solid (11.32 g, yield: 83\%, mp 103-104 $\left.{ }^{\circ} \mathrm{C}\right) .{ }^{1} \mathrm{H}$ NMR $\left(\mathrm{CDCl}_{3}\right), \delta(\mathrm{ppm}): 1.42\left(\mathrm{t}, 3 \mathrm{H}, \mathrm{CH}_{3}\right), 3.92\left(\mathrm{~m}, 2 \mathrm{H}, \mathrm{CH}_{2}\right)$, 6.85-6.88 (m, 4H, ar), 7.11-7.16 (m, 4H, ar). Elemental analysis calculated (\%) for $\mathrm{C}_{14} \mathrm{H}_{13} \mathrm{NS}$ : C, 73.97\%; $\mathrm{H}, 5.76 \%$;, $6.16 \% ; \mathrm{S}, 14.11 \%$. Found: C, $73.83 \%$; H, $5.73 \%$; $\mathrm{N}, 6.13 \%, \mathrm{~S}, 14.10 \%$.

\section{0-Ethyl-3,7-diformylphenothiazine (4c)}

To a $50 \mathrm{~mL}$ glass reactor were added with imidazole $(0.718 \mathrm{~g}, 10.5 \mathrm{mmol})$ and $10 \mathrm{~mL}$ acetonitrile. The mixture were added under stirring with trifluoroacetic anhydride (5.775 g, $27.5 \mathrm{mmol})$ within $5 \mathrm{~min}$, treated dropwise with 10-ethyl-phenothiazine (2c: $1.137 \mathrm{~g}, 5 \mathrm{mmol})$ and then refluxed for $4 \mathrm{~h}$. After adjusting $\mathrm{pH}>7$ with saturated aqueous solution of $\mathrm{Na}_{2} \mathrm{CO}_{3}$, the appearing precipitates were isolated by filtration and washed with water to give a precipitate. The precipitate was dissolved in $\mathrm{CH}_{2} \mathrm{Cl}_{2}$, washed with saturated aqueous $\mathrm{NaHCO}_{3}$, dried over anhydrous $\mathrm{MgSO}_{4}$ and the solvent was removed under reduced pressure to afford 3,7-bis(1,3-bistrifluoracetyl4,5-dihydroimidazole-2-yl)-10-ethylphenothiazine (3c: $3.25 \mathrm{~g}, 87 \%$ ), which was used for the next step without further purification. To a $250 \mathrm{~mL}$ glass reactor were added with $3 \mathrm{c}(5.98 \mathrm{~g}, 8 \mathrm{mmol}), 148 \mathrm{~mL}$ acetonitrile and $77 \mathrm{~mL}$ $1.9 \mathrm{~mol} \mathrm{~L}^{-1} \mathrm{HCl}$. The mixture was refluxed for $3 \mathrm{~h}$ and was 
extracted with ethyl ether after cooling and neutralization. The crude product obtained by removing ethyl ether were purified by column chromatography (silica gel; $n$-hexane/ethyl acetate $=4 / 1)$ to give $4 \mathbf{c}(1.74 \mathrm{~g}, 77 \%, \mathrm{mp}$ $\left.167{ }^{\circ} \mathrm{C}\right) .{ }^{1} \mathrm{H}$ NMR $\left(\mathrm{CDCl}_{3}, \mathrm{ppm}\right): \delta 9.84$ (s, $\left.2 \mathrm{H},-\mathrm{C} \underline{\mathrm{HO}}\right)$, $7.68(\mathrm{dd}, 2 \mathrm{H}$, aromatic hydrogen), 7.59 (s, $2 \mathrm{H}$, aromatic hydrogen), $6.98(\mathrm{~d}, 2 \mathrm{H}$, aromatic hydrogen), $4.05(\mathrm{q}, 2 \mathrm{H}$, $\left.\mathrm{N}-\mathrm{CH}_{2}-\right), 1.50$ (t, $3 \mathrm{H}, \mathrm{N}-\mathrm{CH}_{2}-\mathrm{CH}_{3}$ ). Elemental analysis calculated (\%) for $\mathrm{C}_{16} \mathrm{H}_{13} \mathrm{NO}_{2} \mathrm{~S}: \mathrm{C}, 67.82 ; \mathrm{H}, 4.62 ; \mathrm{N}, 4.94$. Found: C, 67.84; H, 4.60; N, 4.91 .

5,5'-(10-Ethyl-phenothiazine-3,7-diyl)bis(methan-1-yl1-ylidene)bis(4-oxo-2-thioxothiazolidin-3-yl-5-ylidene) diacetic acid ( $\mathbf{S} 3)$

To a stirred $4 \mathbf{c}(0.34 \mathrm{~g}, 1.2 \mathrm{mmol})$ in $\mathrm{CH}_{3} \mathrm{COOH}$ $(30 \mathrm{~mL})$ were added rhodanine-3-acetic acid $(0.476 \mathrm{~g}$,
$2.49 \mathrm{mmol})$ and ammonium acetate $(0.075 \mathrm{~g}, 0.975 \mathrm{mmol})$. The mixture was heated to $120^{\circ} \mathrm{C}$ and the reaction was continued for $2 \mathrm{~h}$ at the temperature. Then the reaction mixture was allowed to cool to room temperature. The solid was collected by filtration and washed with water thoroughly. After drying in air, the crude product was purified by column chromatography on silica gel with $\mathrm{CH}_{2} \mathrm{Cl}_{2} /$ methanol $(10: 1, \mathrm{v} / \mathrm{v})$ as eluant to give $\mathbf{S 3}$ in $86 \%$ yield, mp $>200{ }^{\circ} \mathrm{C} .{ }^{1} \mathrm{H}$ NMR (DMSO-d $\mathrm{d}_{6}$ ), $\delta$ (ppm): 7.75 (s, 2H, $-\mathrm{C} \underline{\mathrm{H}}=), 7.47$ (d, 2H, aromatic hydrogen), 7.40 (s, $2 \mathrm{H}$, aromatic hydrogen), 7.19 (d, $2 \mathrm{H}$, aromatic hydrogen), $4.71\left(\mathrm{~s}, 4 \mathrm{H}, \mathrm{O}=\mathrm{C}-\mathrm{C}_{2}-\mathrm{N}\right), 4.00\left(\mathrm{q}, 2 \mathrm{H}, \mathrm{N}-\underline{\mathrm{C}}_{2}-\right), 1.33$ (t, $3 \mathrm{H}, \mathrm{N}-\mathrm{CH}_{2}-\mathrm{CH}_{3}$ ). Elemental analysis calculated (\%) for $\mathrm{C}_{26} \mathrm{H}_{19} \mathrm{~N}_{3} \mathrm{O}_{6} \mathrm{~S}_{5}: \mathrm{C}, 49.59 \%$; H, 3.04\%; $\mathrm{N}, 6.67 \%$. Found: C, $49.43 \%$;, $3.01 \%$; N $6.53 \%$.

\section{s}

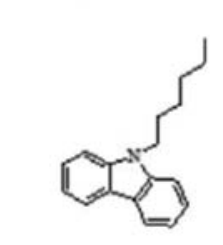

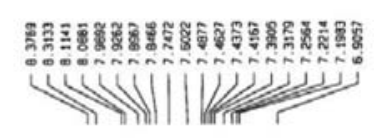
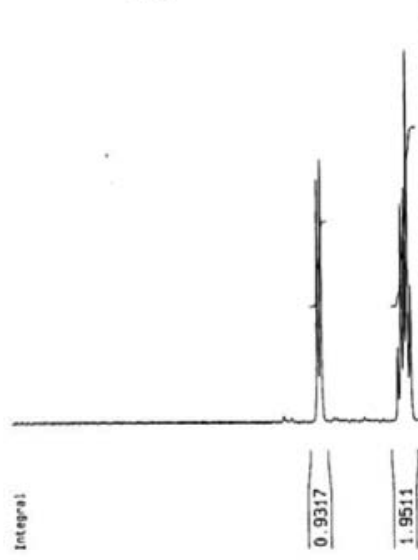

$\stackrel{\vec{z}}{\underline{z}}$

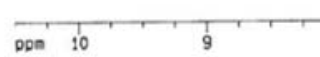

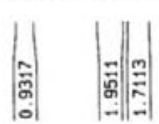

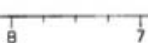

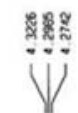

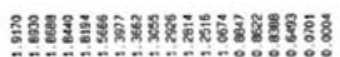
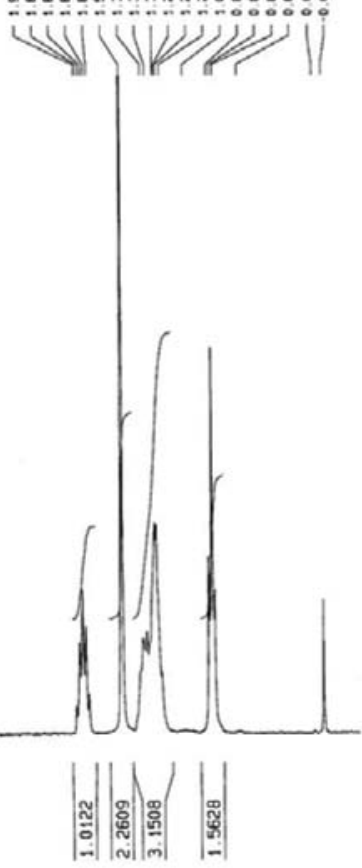

Figure S1. ${ }^{1} \mathrm{H}$ NMR (300 MHz) spectrum of $N$-hexylcarbazole (2a). 
s

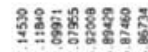<smiles>CCN1c2ccccc2CCc2ccccc21</smiles>
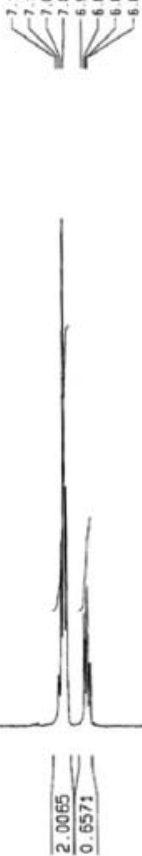

Vิ

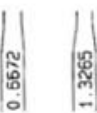

$\mid$

:

ppm

Figure S2. ${ }^{1} \mathrm{H}$ NMR (300 MHz) spectrum of 11-ethyl-iminodibenzyl (2b).

s

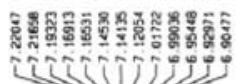

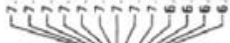<smiles>CCN1c2ccccc2Sc2ccccc21</smiles>
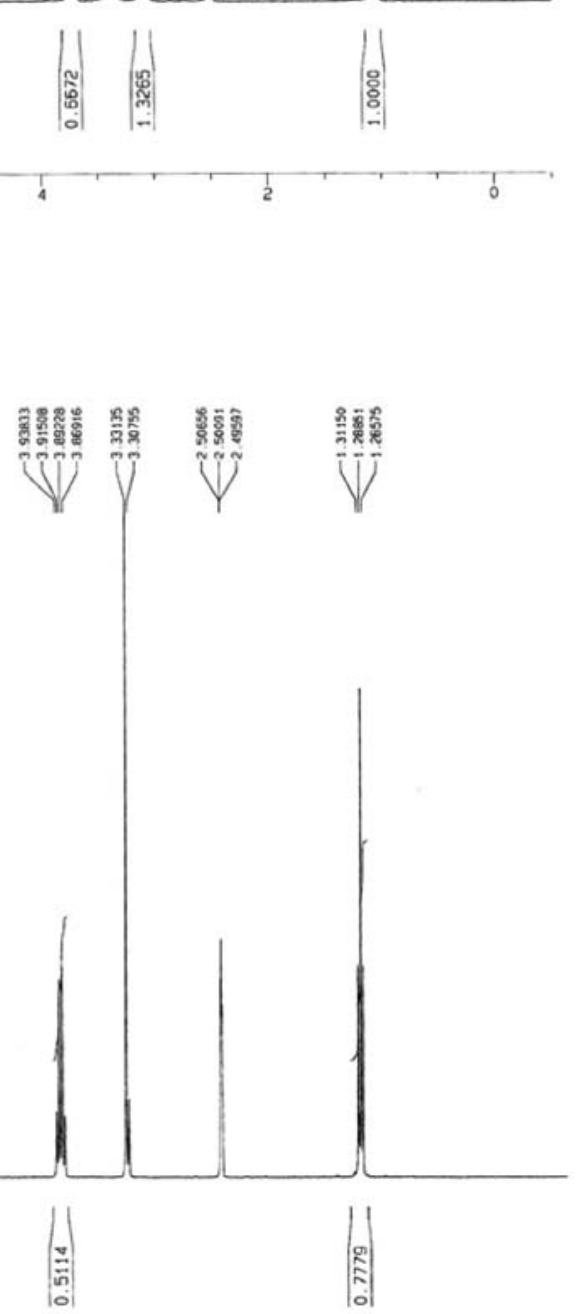

$\stackrel{\square}{\underline{g}}$
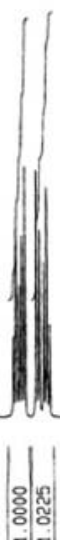

in

io

pom

Figure S3. ${ }^{1} \mathrm{H}$ NMR (300 MHz) spectrum of 10-ethyl-phenothiazine (2c). 


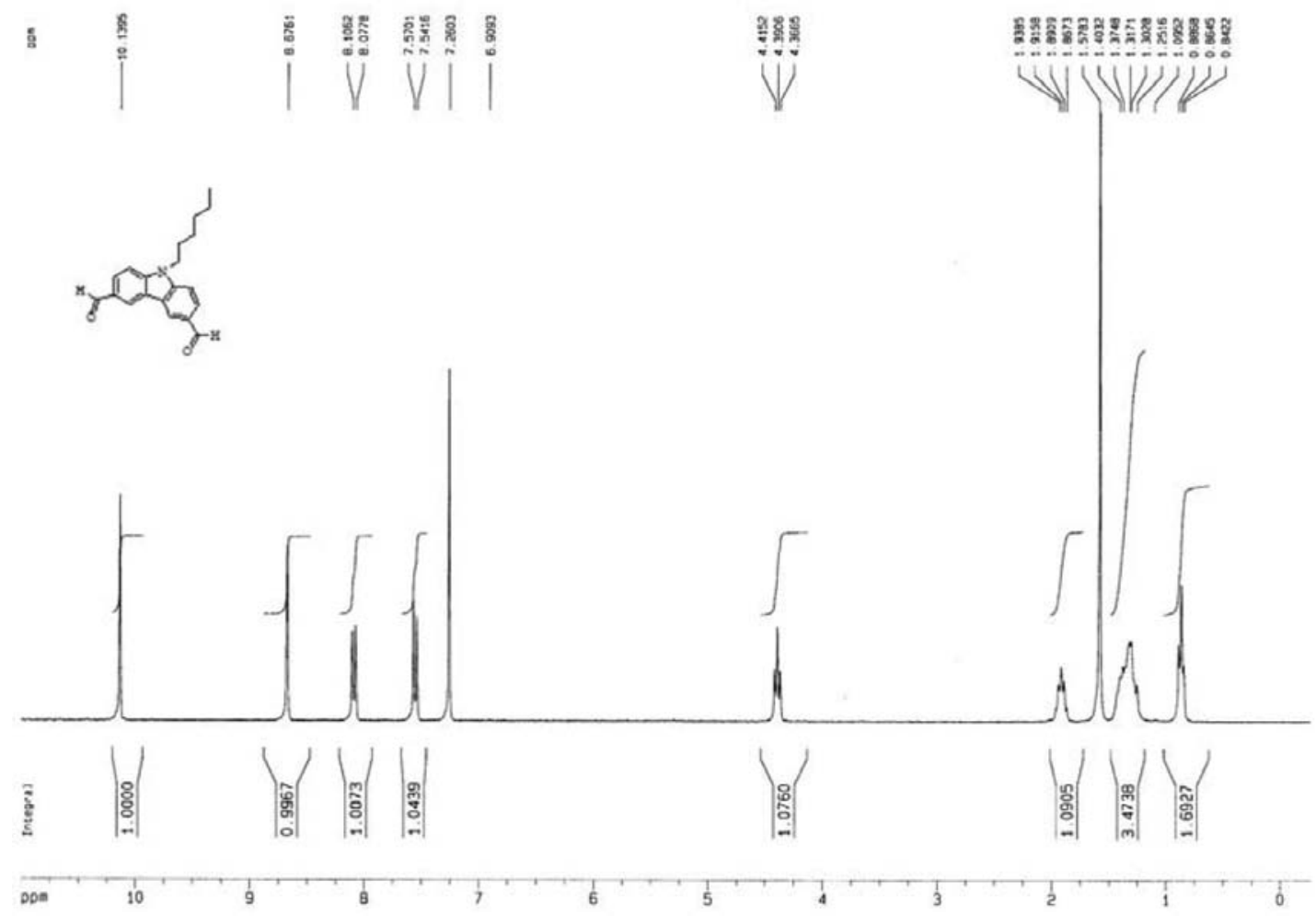

Figure S4. 'H NMR (300 MHz) spectrum of 9-hexylcarbazole-3,6-dicarbaldehyde (4a).

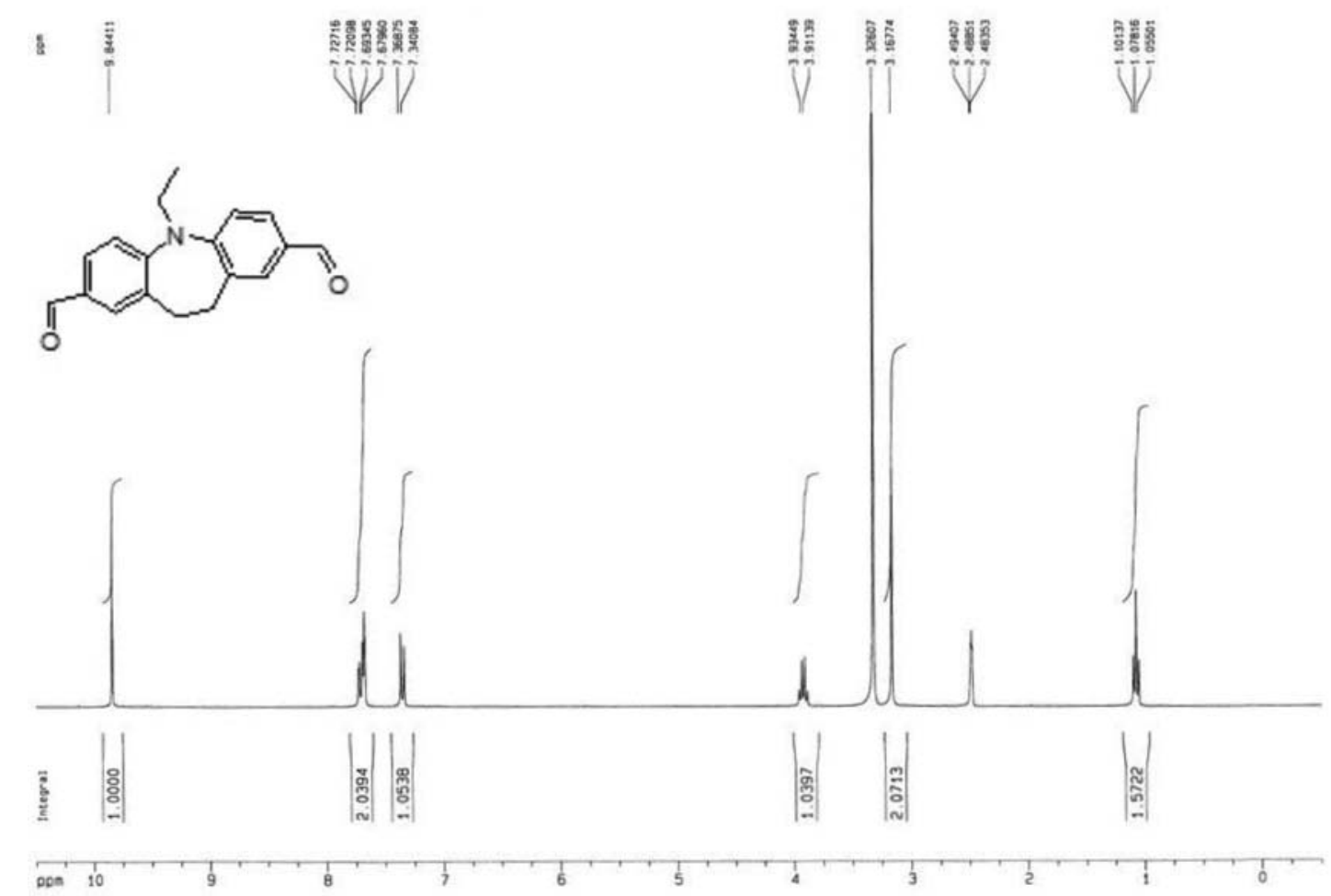

Figure S5. ${ }^{1} \mathrm{H}$ NMR (300 MHz) spectrum of 11-ethyl-3,8-diformyliminodibenzyl (4b). 

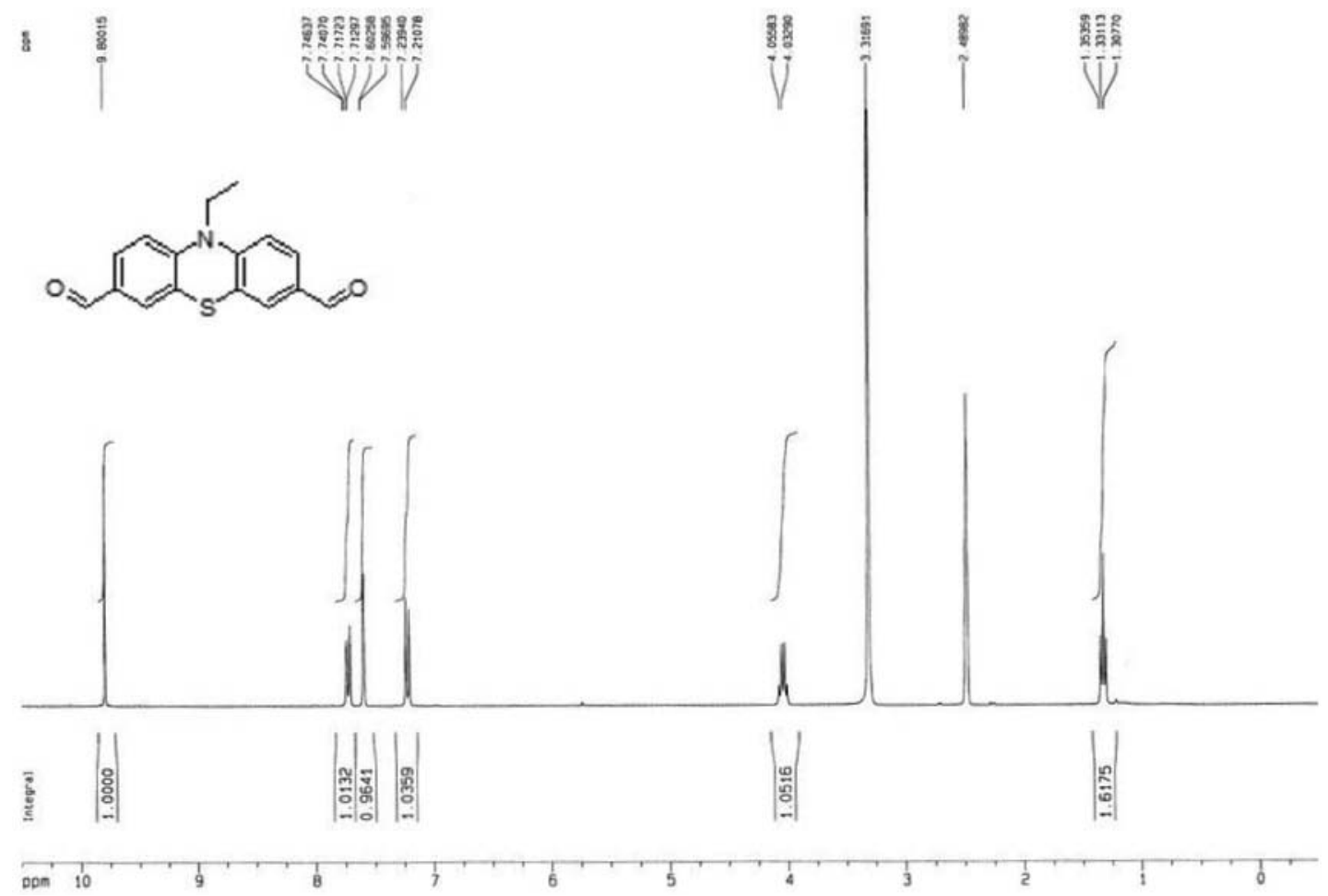

Figure S6. ${ }^{1} \mathrm{H}$ NMR (300 MHz) spectrum of 10-ethyl-3,7-diformylphenothiazine (4c).

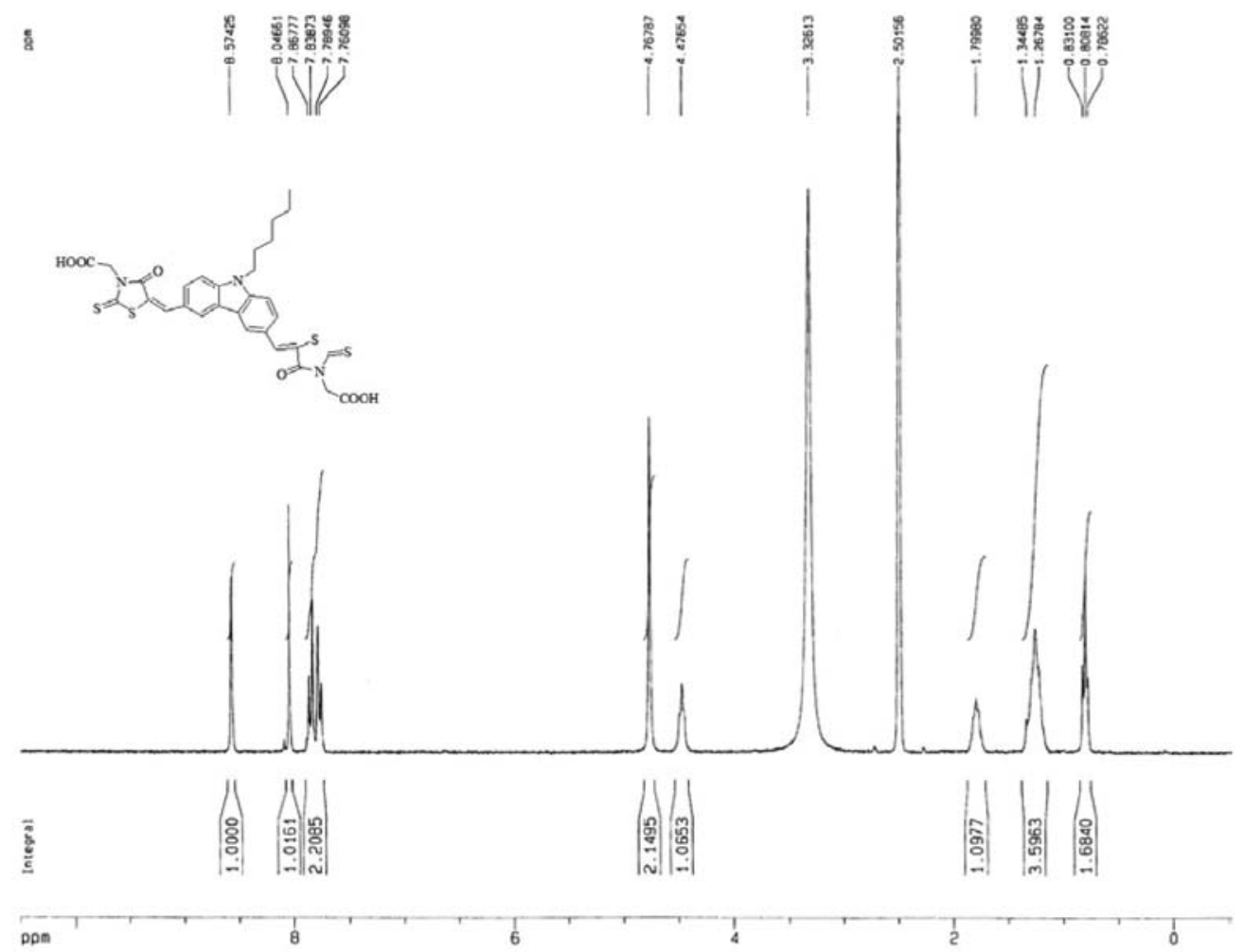

Figure S7. ${ }^{1} \mathrm{H}$ NMR (300 MHz) spectrum of $\mathbf{S 1}$. 
s

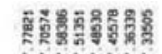

mivin

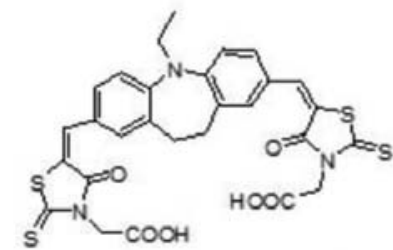
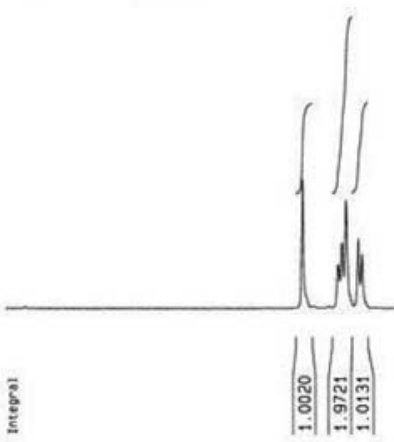

Dpe

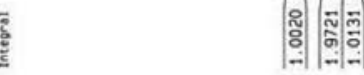

Figure S8. ${ }^{1} \mathrm{H}$ NMR (300 MHz) spectrum of $\mathbf{S 2}$.

8
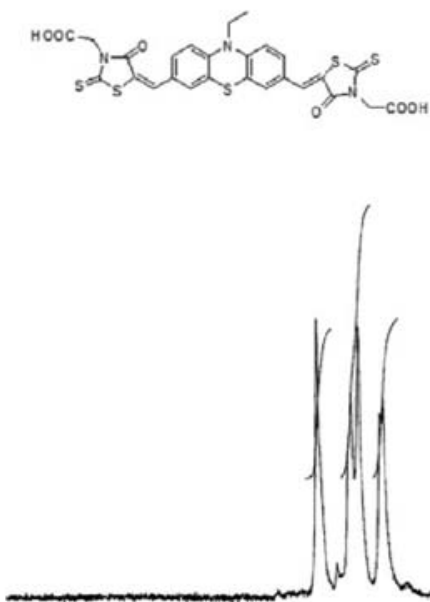

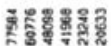

îTî

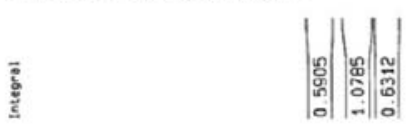

open

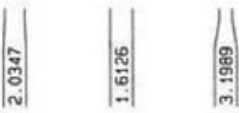

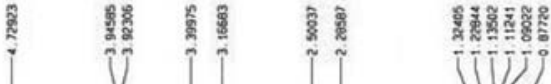
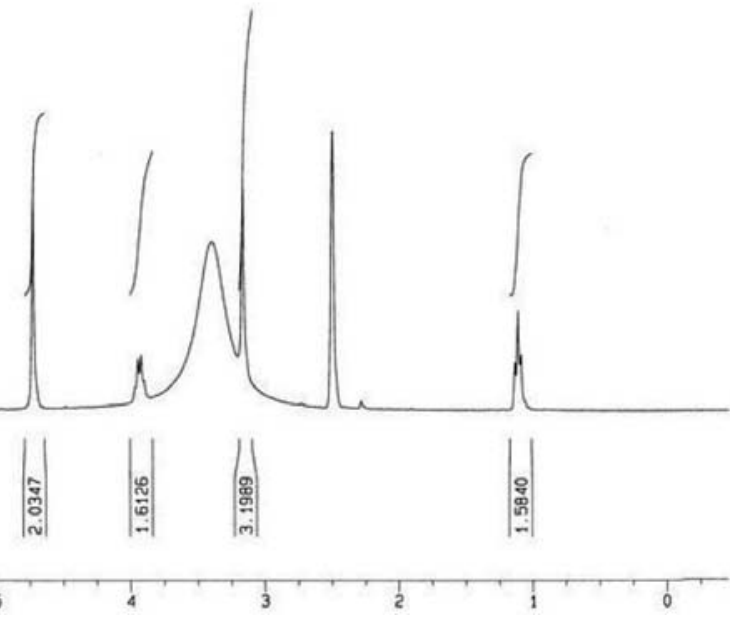

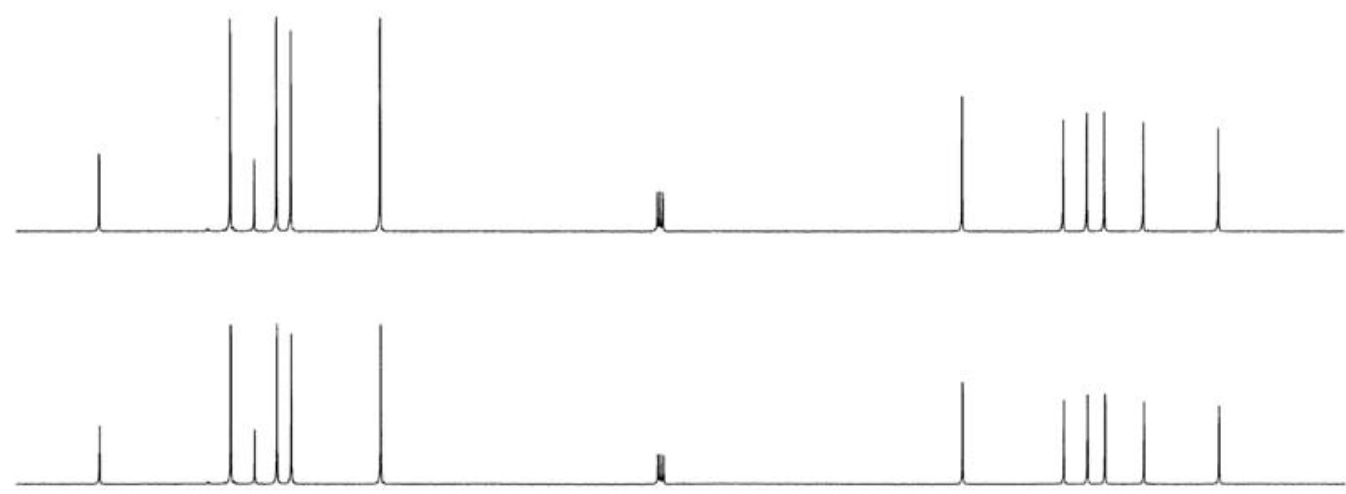

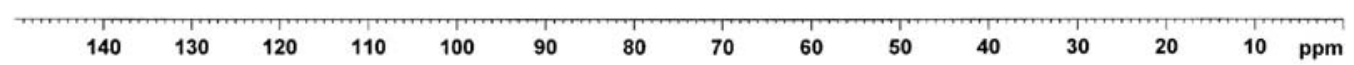

Figure S10. ${ }^{13} \mathrm{C}$ NMR (400 MHz) spectrum of $N$-hexylcarbazole (2a).

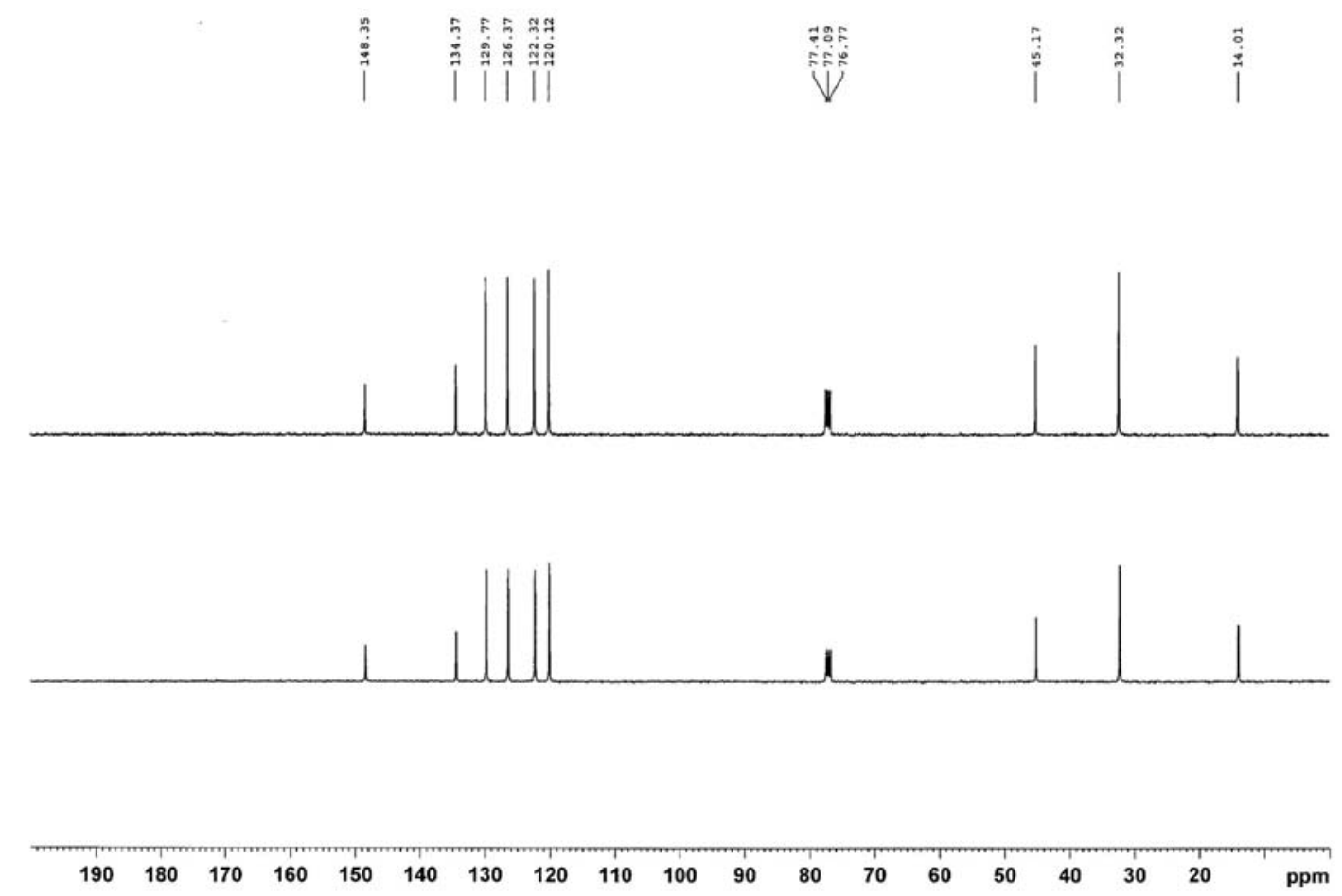

Figure S11. ${ }^{13} \mathrm{C}$ NMR (400 MHz) spectrum of 11-ethyl-iminodibenzyl (2b). 

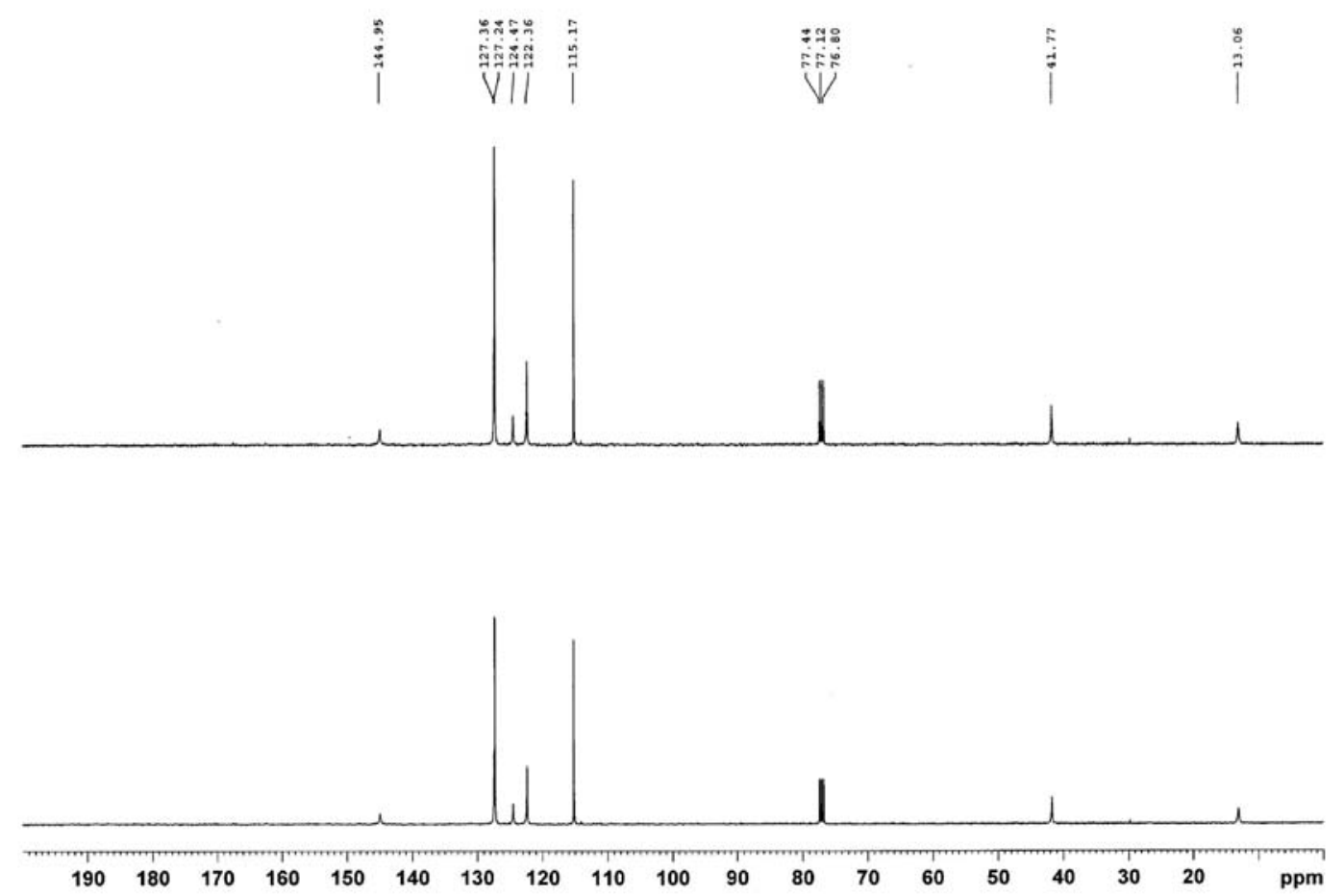

Figure S12. ${ }^{13} \mathrm{C}$ NMR (400 MHz) spectrum of 10-ethyl-phenothiazine (2c).

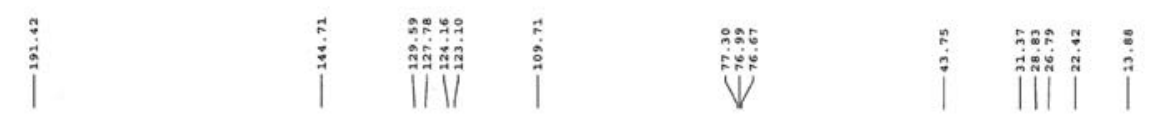
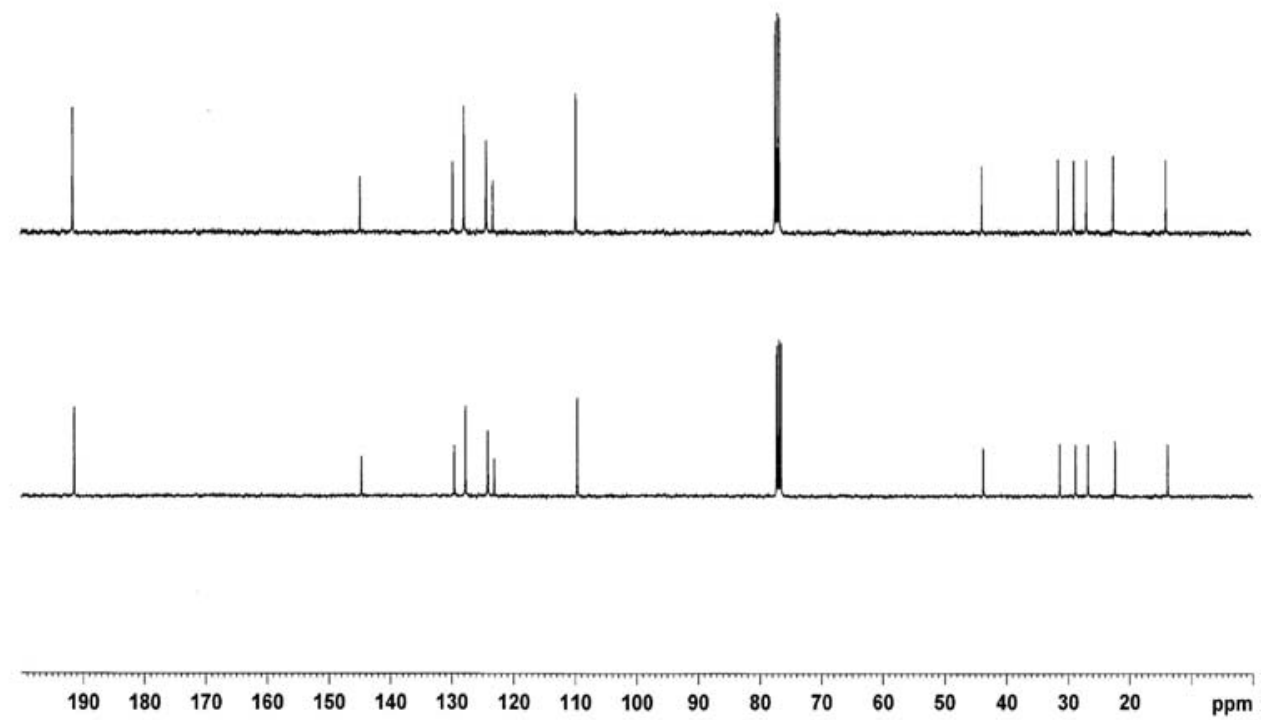

Figure S13. ${ }^{13} \mathrm{C}$ NMR (400 MHz) spectrum of 9-hexylcarbazole-3,6-dicarbaldehyde (4a). 


İ
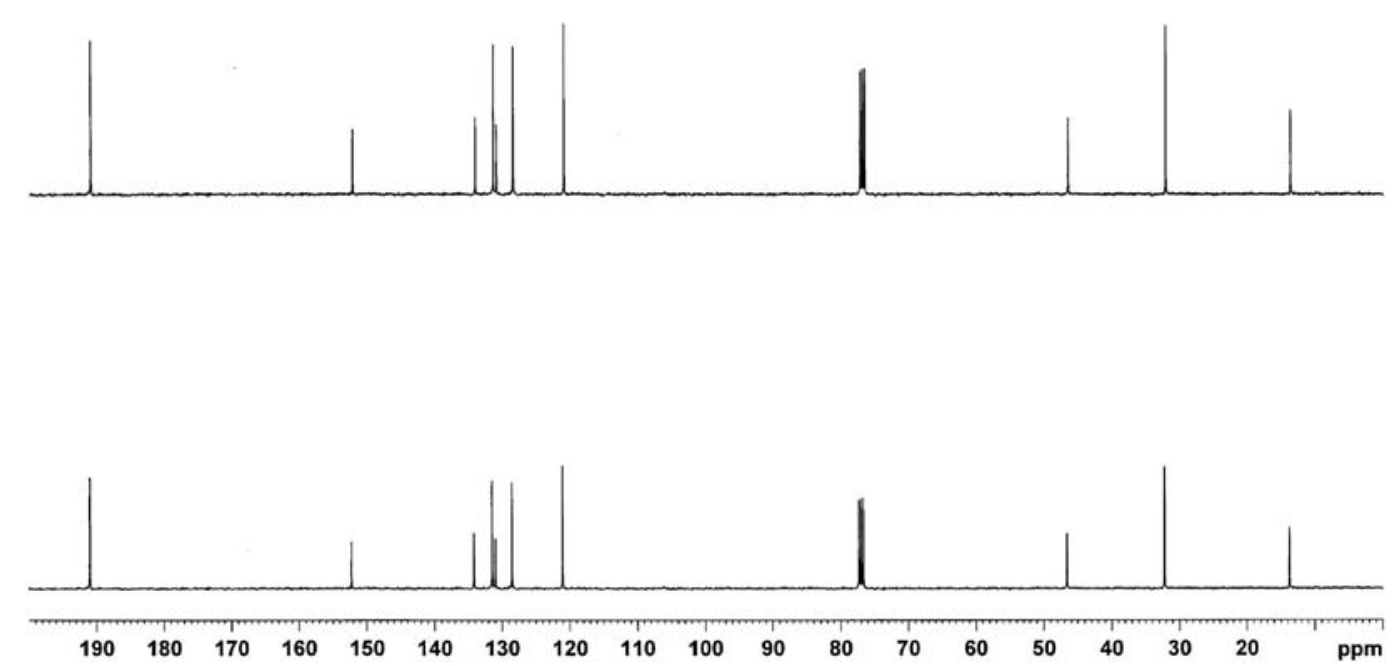

Figure S14. ${ }^{13} \mathrm{C}$ NMR (400 MHz) spectrum of 11-ethyl-3,8-diformyliminodibenzyl (4b).

İ
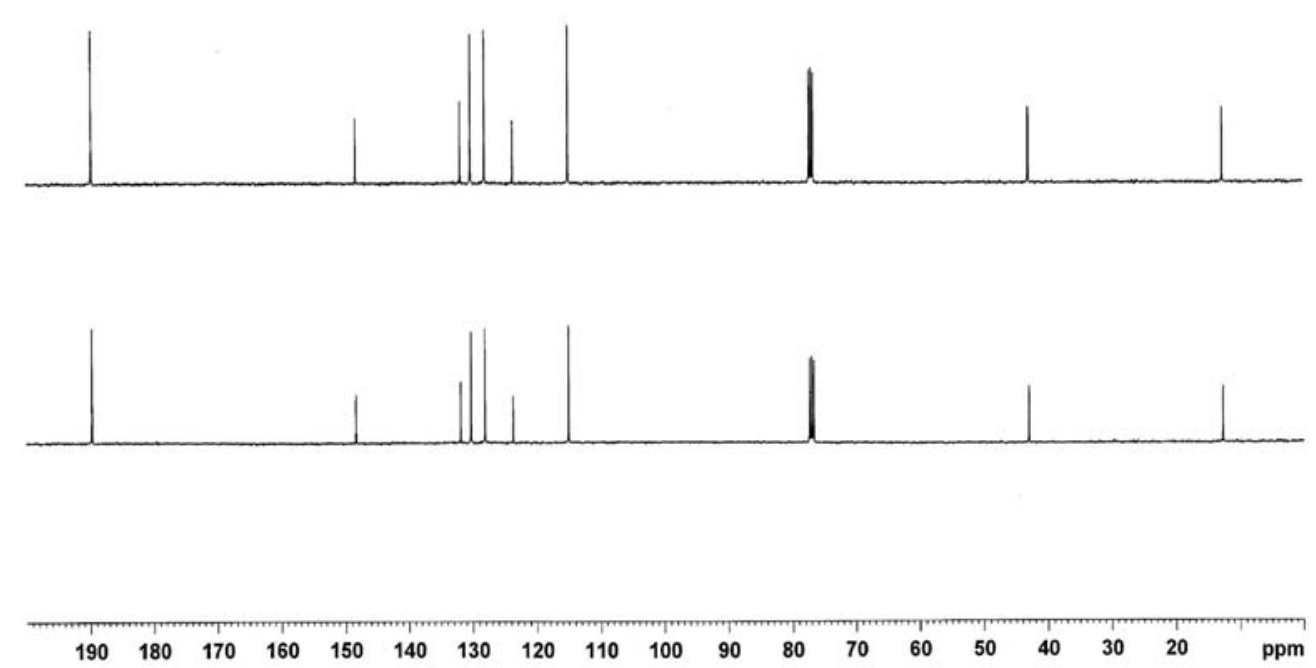

Figure S15. ${ }^{13} \mathrm{C}$ NMR (400 MHz) spectrum of 10-ethyl-3,7-diformylphenothiazine (4c). 